\title{
Temporal variations in hydro-geochemistry and potential health risk assessment of groundwater from lithological diversity of semi-arid region, Western Gujarat, India
}

\author{
K. D. Shirke ${ }^{1} \cdot$ Ajaykumar Krushna Kadam² $^{2}$ - N. J. Pawar ${ }^{3}$
}

Received: 12 March 2020 / Accepted: 13 May 2020 / Published online: 4 June 2020

(c) The Author(s) 2020

\begin{abstract}
The temporal changes in hydro-geochemistry of groundwater from lithological diversity of Amba Dongar area were assessed from human health risk point of view. In view of this, 104 samples were collected in post- (POM) and pre-monsoon (PRM) seasons to understand the ionic concentrations and seasonal variations in major cations and anions. Based on concentration of physicochemical parameters it is inferred that groundwater quality is good for drinking and most of the parameters are within allowable limit of the World Health Organisation (WHO). However, EC, TDS, $\mathrm{Ca}^{2+}$ and $\mathrm{HCO}_{3}{ }^{-}$exceed the desirable while $\mathrm{NO}_{3}$ and $\mathrm{F}$ content are found beyond the permissible limits. The results $33 \%$ and $15 \%$ samples for nitrate and $60 \%$ and 63\% samples for fluoride in POM and PRM, respectively, are above permissible limits of WHO, indicating a high health risk to inhabitants. The Piper's trilinear diagram depicts $\mathrm{Ca}^{2+}-\mathrm{Mg}^{2+} \mathrm{HCO}_{3}{ }^{-}$as major water type in both the seasons and the plots diagram that the chemical rock weathering and rock-water interaction are responsible for modifying the groundwater chemistry. Further, the total hazard index indicates that children have higher risk than adults in both. Hence, antipollution filters and rainwater recharging structures are recommended as an action to be taken to lessen the health hazard.
\end{abstract}

Keywords Fluoride and nitrate contamination · Groundwater · Human health risk assessment - Amba Dongar area · Western Gujarat

\section{Introduction}

In India, more than 66 million people are at risk due to consuming groundwater contaminated by various chemical elements such as fluoride, nitrate, arsenic and boron in 19 states, which includes 6 million children below 14 years (Mukherjee and Singh 2018). Most of the population in India is mainly depending on groundwater as prime source

Ajaykumar Krushna Kadam

kadamajaykumar1@gmail.com

K. D. Shirke

krushnathshirke@gmail.com

N. J. Pawar

dr.njpawar@gmail.com

1 Department of Geology, Savitribai Phule Pune University, Pune, Pune, Maharashtra 411 007, India

2 Department of Environmental Sciences, Savitribai Phule Pune University, Pune, Pune, Maharashtra 411 007, India

3 Dr. D. Y. Patil Vidyapeeth, Pimpri, Pune 411018, India of water for drinking, irrigation, industrial and for livestock (Brindha et al. 2017a; Kammoun et al. 2018; Mundalik et al. 2018; Wagh et al. 2018). The problem of water scarcity is also increasing due to population explosion in India (Singh et al. 2013; Surendran et al. 2017; Huber García et al. 2018). This water scarceness leads to increase in the use of groundwater for urban as well as rural sector (Taiwo 2012; Huang et al. 2013; Singh et al. 2015; Kumar et al. 2018). On one hand water scarcity is increasing and the other the water pollution is also growing due to urbanisation and industry. Particularly the agriculture runoff (Vetrimurugan et al. 2013; Pastén-Zapata et al. 2014; Singh 2014; Saidi et al. 2009; Hamdi et al. 2018) and changes in land use pattern (Huang et al. 2013) urbanisation (Selvakumar et al. 2017) are the basic cause of groundwater contamination (Jiang et al. 2009; Pastén-Zapata et al. 2014; Kumar et al. 2017; Magesh et al. 2017; Adimalla et al. 2019; Bahrami et al. 2020; Wagh et al. 2020) Egbi et al. (2020) studied Nitrate contamination in groundwater and surface water from Ghana area showed that $70 \%$ infants having health risk from groundwater while $79 \%$ high risk of surface water contamination to infants. 
Kadam et al. (2019) studied the groundwater contamination by boron and fluoride and its risk assessment from Western part of India and found that children having moderated noncarcinogenic risk in study region. Ahada and Suthar (2018) carried out assessment of nitrate contamination in groundwater and its health risk from a part of Punjab, India, the results shows that nitrate mainly transpired from fertilizers, solid waste and pose severe health risk to children below 5 years. Kammoun et al. (2018) evaluated the groundwater quality by integrated approaches from parts of NE Tunisia from which he found that recharged water from agricultural land use from study region and urban activities are reason for contamination. Adimalla and $\mathrm{Li}$ (2019) studied the fluoride and nitrate occurrence in groundwater and its health risks with geochemical mechanisms from southern parts of India and found that fluoride mainly oose out from host rock while nitrate come from fertilizers which result in high health risk to children than adults. Wang et al. (2016) studied the nitrate contaminating factor that contribute to groundwater. It was observed that overuse of fertilizers and discharge of wastewater are the main reason in north china plain.

Li et al. (2014) carried out a research on source and evaluation of groundwater pollution and allied health risk in an industrial area from northwest China. The groundwater of the area mainly is polluted with the fluoride from F-containing minerals. Nitrate comes mainly from agricultural practices and other heavy metal due to the industrial activity affecting mainly health of human. Vetrimurugan and Elango (2015a, b) reported that the groundwater is unsuitable for drinking due to poor flushing of groundwater into the sea and elevated concentration of fluoride and nitrate near surface endorse the influence of manures. Wu and Sun (2016) studied groundwater contamination and associated human health risk by agricultural and industrial activities, Mid-west China found that serious pollution present in alluvial plain due to huge population density, intensive manmade activities like industrialisation, high water demand, and susceptible environs results into, high health risk to children than adults by oral ingestion exposure pathway. Kale and Pawar (2017) studied from the semi-arid part of western India that enrichment of fluoride in groundwater is one of the causal factors for Urolithiasis. Yousefi et al. (2018) carried out an investigation on possible health risk regarding fluoride contaminated drinking water in Iran. Groundwater in the Poldasht city has abundant potential to impose adverse impact on young population that effects on villagers. The studies from different regions of the world done to assess groundwater contamination such as Pastén-Zapata et al. (2014) studied aquifer underneath a sub-humid to humid region in NE Mexico shows that nitrate isotopes and halide ratios have a varied mixture of nitrate causes and alterations. Höckenreiner et al. (2015) found that groundwater is contaminated with polycyclic aromatic hydrocarbons from part of Germany. The local bacteria were used to reduce the contaminated groundwater with PAH.

The nitrate concentration in groundwater is on upsurge by various processes such as irrigation return flow (Ahada and Suthar 2018; Wagh et al. 2017), superfluous practices of manures (Adimalla and Li 2019; Ahada and Suthar 2018), destitute septic schemes, leaky public drains (Wang et al. 2016) dairy and poultry farming (Ahada and Suthar 2018) anthropologic and animal wastes (Ramesh and Elango 2012; Brindha et al. 2017b; Ostad-Ali-Askari et al. 2017; Wagh et al. 2017, 2018). The groundwater quality significantly deteriorated due to farming practices where nitrogen is main nutrient for crop growth (Ahada and Suthar 2018). The excessive use of nitrogenous manures and compost enhance the denitrification capacity of soil, resulting in leaching of nitrogen in groundwater (Wagh et al. 2017).

Human body requires fluoride in trace amounts for bones and dental enamel strengthening. However, if it exceeds the limits in drinking water it causes fluorosis, a dreaded, incurable disease. The low concentration of $\mathrm{F}(<0.1 \mathrm{mg} / \mathrm{l})$ in drinking water can result into dental decay while high F level can cause adverse health effects (Kale and Pawar 2017; Yousefi et al. 2018). According to WHO standards the fluoride levels beyond $1 \mathrm{mg} / \mathrm{L}$ result into dental fluorosis (Singh et al. 2018). Whereas if $F$ values are ranging from 0.5 to $1 \mathrm{mg} / \mathrm{L}$, it is considered as good water for domestic use (Yousefi et al. 2018). The geogenic source for fluoride in groundwater is the occurrence of mineral fluorite in geological formation underlying the area. Apart from this, the fluoride concentration is also elevated due to use of agrochemicals and other alike anthropogenic activities (Datta and Tyagi 1996; Daniel and Karuppasamy 2012). In addition, it has been detected in areas where high calcite deposition occurs in alkaline situations (Mrazovaca et al. 2013; Su et al. 2013).

The literature review shows that plenty of literature is available on geology, economic importance, REE and trace element content and, genesis of fluorite in Amba Dongar area. However, the mining of fluorite has been done for many years in study area, but its overall effect on the tribal people residing in the vicinity of mining site is not studied by any researcher therefore, this is an ideal virgin site to study the effect of trace metals in general and fluoride in particular that have migrated over the years from carbonatite and associated lithologies to groundwater aquifers and soils. In view of this, the present study is undertaken for detecting the concentration levels of major cations and anions, trace metals as well as the hazardous fluoride in groundwater from Amba Dongar area and its effect on human health. Also, the temporal variations in hydro-geochemistry to investigate the source, occurrence and hydrological processes influencing the groundwater have been studied. 


\section{Study area}

The alkaline carbonatite complex of Amba Dongar (Latitudes $21^{\circ} 58^{\prime} 16^{\prime \prime} \mathrm{N}$ to $22^{\circ} 03^{\prime} 30^{\prime \prime} \mathrm{N}$ and Longitudes $74^{\circ} 05^{\prime} 51^{\prime \prime} \mathrm{E}$ to $74^{\circ} 08^{\prime} 24^{\prime \prime} \mathrm{E}$ ) lies about $38 \mathrm{~km}$ south of Chhota Udaipur in western India. The entire area around Amba Dongar is covered by Bagh sandstones, Lime stones, basalts of the Deccan Traps and carbonatites exposed in the Lower Narmada valley of West Central India (Bose 1984). Also, the area is structurally disturbed, located in the rift region of Narmada basin which is observed as an antique plane of weakness where tectonic activities have taken place (West 1962).

The study area receives an average annual rainfall ranging from 900 to $1000 \mathrm{~mm}$ during June to September. It experiences semi-arid climate and moderate humidity with average temperature ranging from $41^{\circ} \mathrm{C}$ during April and May to about $18{ }^{\circ} \mathrm{C}$ during December. The area can be accessed by metalled and unmetalled roads that experiences water scarcity in summer months, i.e. March onwards as the daily temperature is increased to more than $40{ }^{\circ} \mathrm{C}$.

\section{Geology}

The Amba Danger area is famous for its fluorite deposit which is one of the largest in Asia. The Alkaline Rocks occurs as intrusive bodies of phonolitic nephelinite and nephelinite with associated carbonatites forming ring dykes and plug like bodies intrusive into Deccan basalts that overlie Cretaceous sandstone and limestone.

The study area consists of varied geological formations from upper cretaceous, tertiary to quaternary. The Amba Danger carbonatite complex consists of seven units of rocks as soviet, Ankerite, Carbonatite breccia, post-carbonatite basalt, and intruded alkaline plugs. The carbonatite-alkalic complex of Amba Danger is situated on the north western periphery of the Deccan Trap province, which is underlain by Bagh sediments and Dharwar metamorphics. The area is surrounded by tertiary shales, sandstones, limestones and conglomerates. Intrusions of quartz reefs are also seen. In nutshell the area comprises of igneous, sedimentary and metamorphic rock types (Figs. 1, 2).

\section{Hydrogeology}

The groundwater presents in unconfined and confined aquifer environments. Wet zones of unconsolidated superficial alluvium and battered regions, superficial interconnected and cracked host rocks create unconfined aquifers, while multifaceted aquifer underneath impermeable soil horizons in alluvium environments and interflow regions of igneous rock, inter-trappean beds, deep placed fissure areas, clip regions in basalts, granites and gneisses crated the semi confined to confined zones in study area (Fig. 2).

The study area is having varied groundwater extraction structures such as dug wells, hand-pump and bore wells, and their yields mainly depend on the aquifer types either alluvial/soft rock, hard rock or both. In phreatic conditions, dug well depth varies from few meters to more than $25 \mathrm{~m}$. The bore well depth is varying from 30 to $90 \mathrm{~m}$ depending on the thickness of unconsolidated and consolidated formations of the area. The shallow bores well are drilled up to 60 to $80 \mathrm{~m}$ depth and used for irrigation purpose. The moderate to low yield prospect of tube wells and dug cum bore wells is estimated to be 100 to $500 \mathrm{~L}$ per minute, having good quality water and within permissible limit (CGWB 2013). The hard rock terrain with high slope in the area, result in less recharge to aquifers and some of the existing bore wells have become non-operational.

\section{Material and methodology}

In order to study the temporal variations in hydro-geochemistry, occurrence of fluoride and nitrate in groundwaters and to identify their possible sources influencing the subsurface aqueous environment, the sampling was done in Amba Danger area. Random sampling technique was adopted, due to the accessibility to the sampling sites which was unfeasible due to rugged and dissected terrain. Secondly, the impact assessment of different lithologies on enrichment of fluoride, Nitrate in particular and trace elements in general was to be studies to pinpoint the natural sources of these elements.

The sampling of groundwater was divided into surface water, groundwater water from shallow aquifer (Dug wells) and Deeper aquifers (Bore wells). In all 52 representative samples from both the types of wells and surface water were collected (Fig. 3) during post-monsoon (POM) season (December 2014) and pre-monsoon (PRM) season (March 2015). Only one surface water samples were collected, 18 dug wells and 33 bore well samples were collected depending on field feasibility and to study and locate the sources of enrichment of elements in water. The surface water samples were collected from flowing streams. The collected water samples were labelled properly and operating conditions of well, $\mathrm{pH}, \mathrm{EC}$, well depth, static water level, lithology were recorded in the field. The dug, bore and surface waters from Amba Dongar carbonatite complex were sampled in $1 \mathrm{~L}$ capacity polyethylene pre-cleaned bottles. The operating conditions of the wells along with other environmental influences were recorded wherever possible. The $\mathrm{pH}$ and electric conductivity (EC) were measured using handheld EC and $\mathrm{pH}$ meter at sampling location site. The samples were suction filtered using 0.45 -micron membrane filter papers. The analysis of major cations $\left(\mathrm{Na}^{+}, \mathrm{K}^{+}, \mathrm{Ca}^{2+}\right.$ and $\left.\mathrm{Mg}^{2+}\right)$ and 

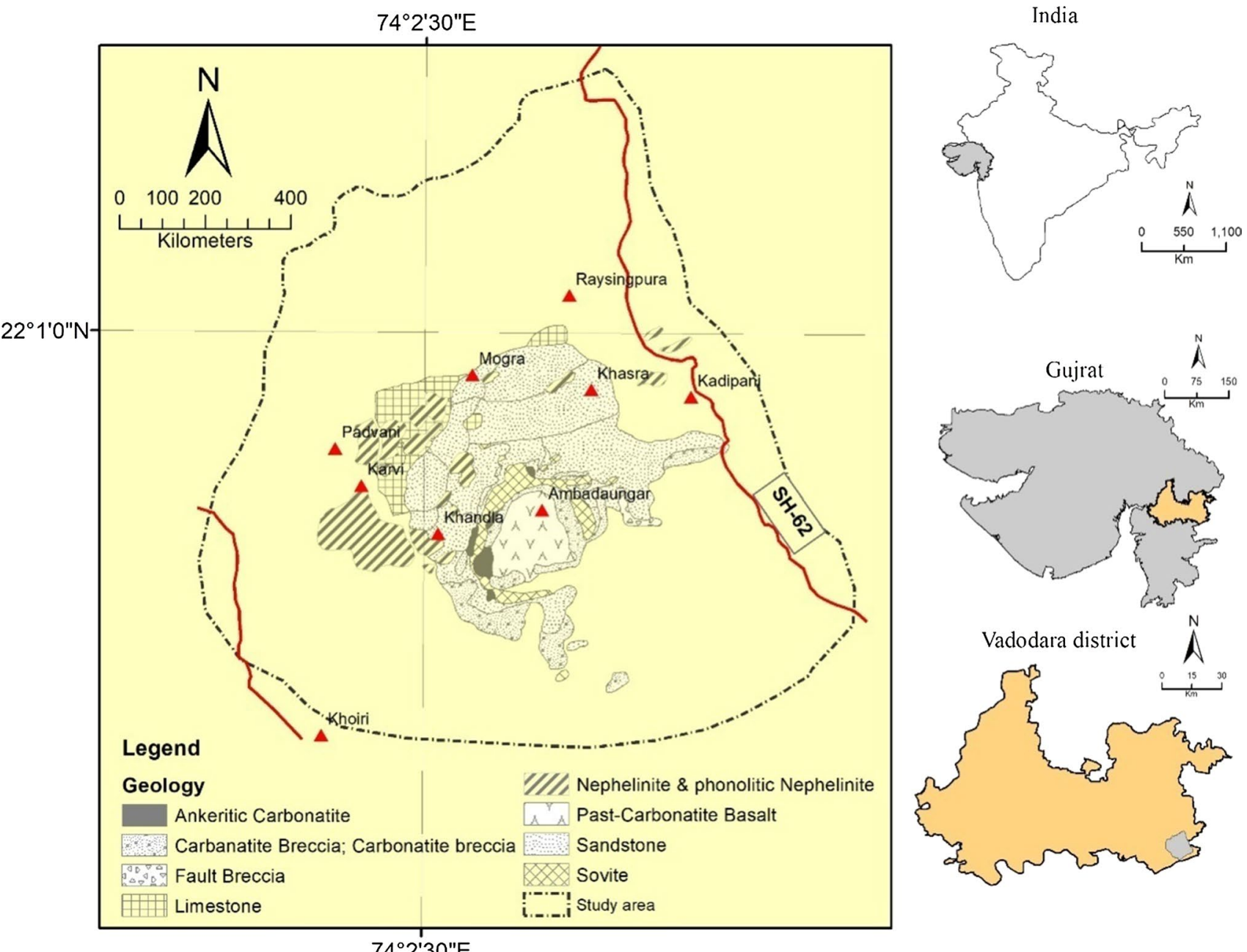

$74^{\circ} 2^{\prime} 30^{\prime \prime} \mathrm{E}$

Fig. 1 Location and geology of study area

anions $\left(\mathrm{HCO}_{3}{ }^{-}, \mathrm{Cl}^{-}, \mathrm{SO}_{4}{ }^{2-}, \mathrm{NO}_{3}{ }^{-}\right.$and $\left.\mathrm{F}^{-}\right)$were done using high-performance ion chromatography (HPIC) and standard titration methods, following Standard Procedures (APHA 1995). Total dissolved solids (TDS) were calculated using lenntech online software. The $\mathrm{CO}_{3}$ and $\mathrm{HCO}_{3}$ were analysed by titrating with $\mathrm{HCl}$. Total hardness $(\mathrm{TH})$ as calcium carbonate $\left(\mathrm{CaCO}_{3}\right)$ was determined by titration method using EDTA solution, while the cations such as $\mathrm{Ca}$ and $\mathrm{Mg}$ also determined by titration method using EDTA solution having murexide and Eriochrome Black T as indicator, respectively (APHA 1995). The Na and K were determined by 128 Systronic make flame photometer with reproducibility of $\pm 1 \%$ fs $\pm 2 \%$ in low concentration. The lower and higher detection limit for sodium and potassium is $2 \mathrm{ppm}$ and $100 \mathrm{ppm}$ and $\mathrm{K}$ is $0.1 \mathrm{ppm}$ to $20 \mathrm{ppm}$, respectively. Dionex make DX-600 HPIC machine was used for the analyses of anions $\left(\mathrm{Cl}^{-}, \mathrm{SO}_{4}{ }^{2-}, \mathrm{NO}_{3}{ }^{-}\right.$and $\left.\mathrm{F}^{-}\right)$in the groundwater samples. The cations and anions charge balance error (CBE) was less than $5 \%$ was calculated by lennetch online software (Domenico and Schwartz 1990). The equation (Eq. 1) to calculate the CBE is as follows

$\mathrm{CBE}=\frac{\sum \text { Cation }-\sum \text { Anion }}{\sum \text { Cation }+\sum \text { Anion }} \times 100$

The data were further utilised for generation of geochemical plots, hydrochemical classification of groundwater and for identification of the parameters influencing water chemistry. The maps were also generated in GIS environment using ordinary Kriging interpolation method in geostatistical Analyst tool of Arc GIS software.

The groundwater in the area contains dissolved constituents on account of its interaction with aquifer rocks. The dissolved constituents in the groundwater have been classified on the basis of their major and trace element concentrations. The water types of analysed samples were plotted on the Piper diagram AquaChem software (AquaChem v4.0). To 


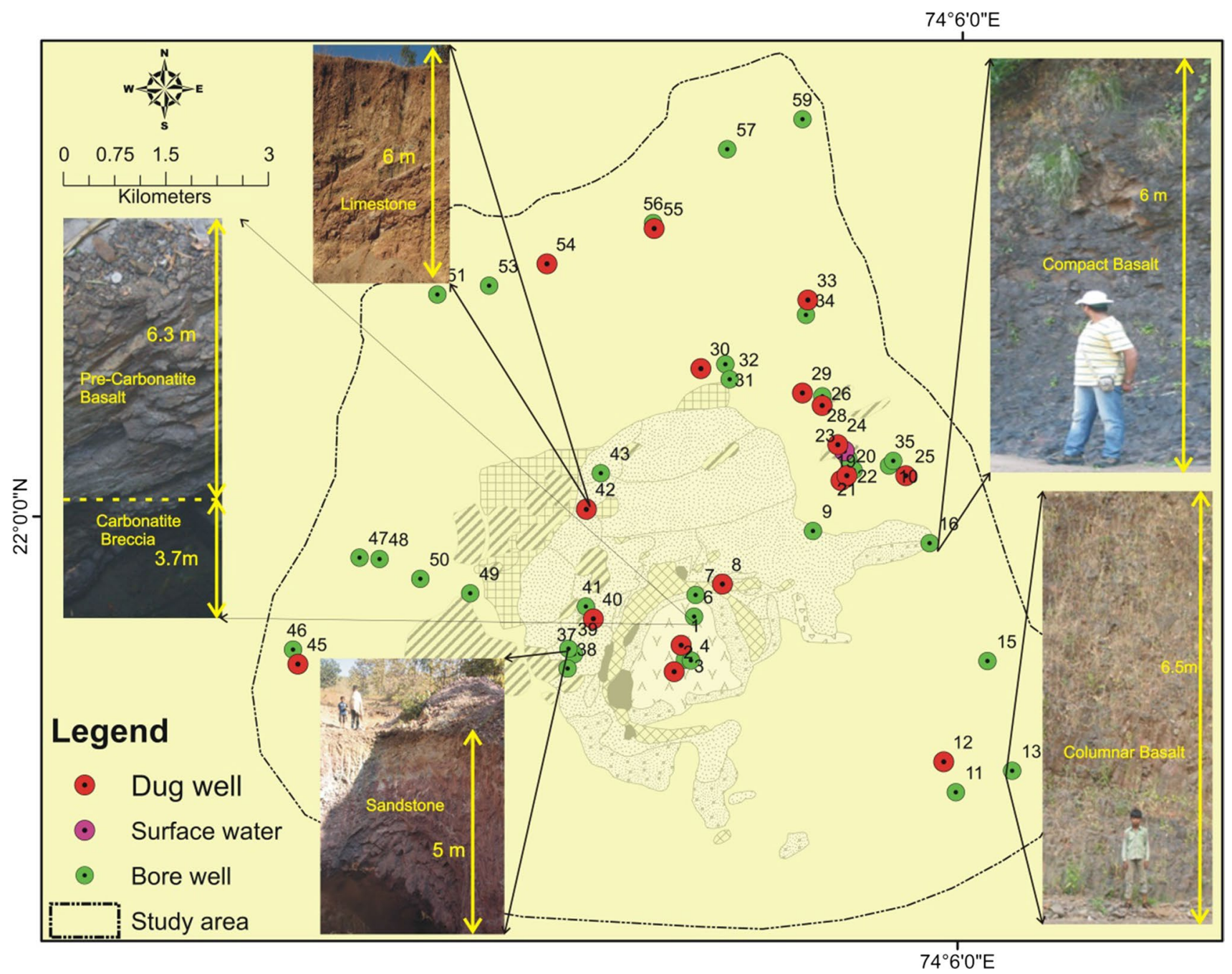

Fig. 2 Geological profile at different locations

understand the dominance of either precipitation, rock matter or evaporation process, Gibbs (1970) designed two semi log diagrams which are now known as the Gibbs diagrams, in which graphs of TDS versus $\mathrm{Cl}^{-} /\left(\mathrm{Cl}^{-}+\mathrm{HCO}_{3}{ }^{-}\right)$and TDS versus $\left(\mathrm{Na}^{+}+\mathrm{K}^{+}\right) /\left(\mathrm{Na}^{+}+\mathrm{K}^{+}+\mathrm{Ca}^{2+}\right)$ for anions and cations are plotted.

\section{Human health risk assessment of fluoride and nitrate}

Due to drinking of contaminated water there will be many problems arise out in India and world (Karyab et al. 2019; Quijano et al. 2017; Li et al. 2016a, b; Adimalla et al. 2019; Karande et al. 2020). The health problem mainly arises from the contaminated air, water and soil from surrounding environment so it is necessary to assess these resources closely. Health risk assessment method is widely used to know the exposure risk of water contaminants like nitrate, fluoride and boron by taking into consideration its use for drinking, dermal interaction and breathe (Kadam et al. 2019; Narsimha and Rajitha 2018). Conversely, in present study drinking water was considered as a source of foremost contact pathway. In the study, to ascertain the health risk the water quality parameters like fluoride and nitrate were considered. The United States Environmental Protection Agency (USEPA) has developed a method to asses of human health risk by following four step (1) identification of hazard, (2) dose response assessment, (3) exposure assessment, and (4) risk characterisation (Narsimha and Rajitha 2018). As per the USEPA fluoride and nitrate elements have non-carcinogenic risks to children and adults. In exposure assessment the average daily dosage (ADD) of fluoride and nitrate through groundwater used for drinking purpose was calculated by using Eq. (2) (USEPA 1991, 2006; Narsimha and Rajitha 2018; Li et al. 2014): 


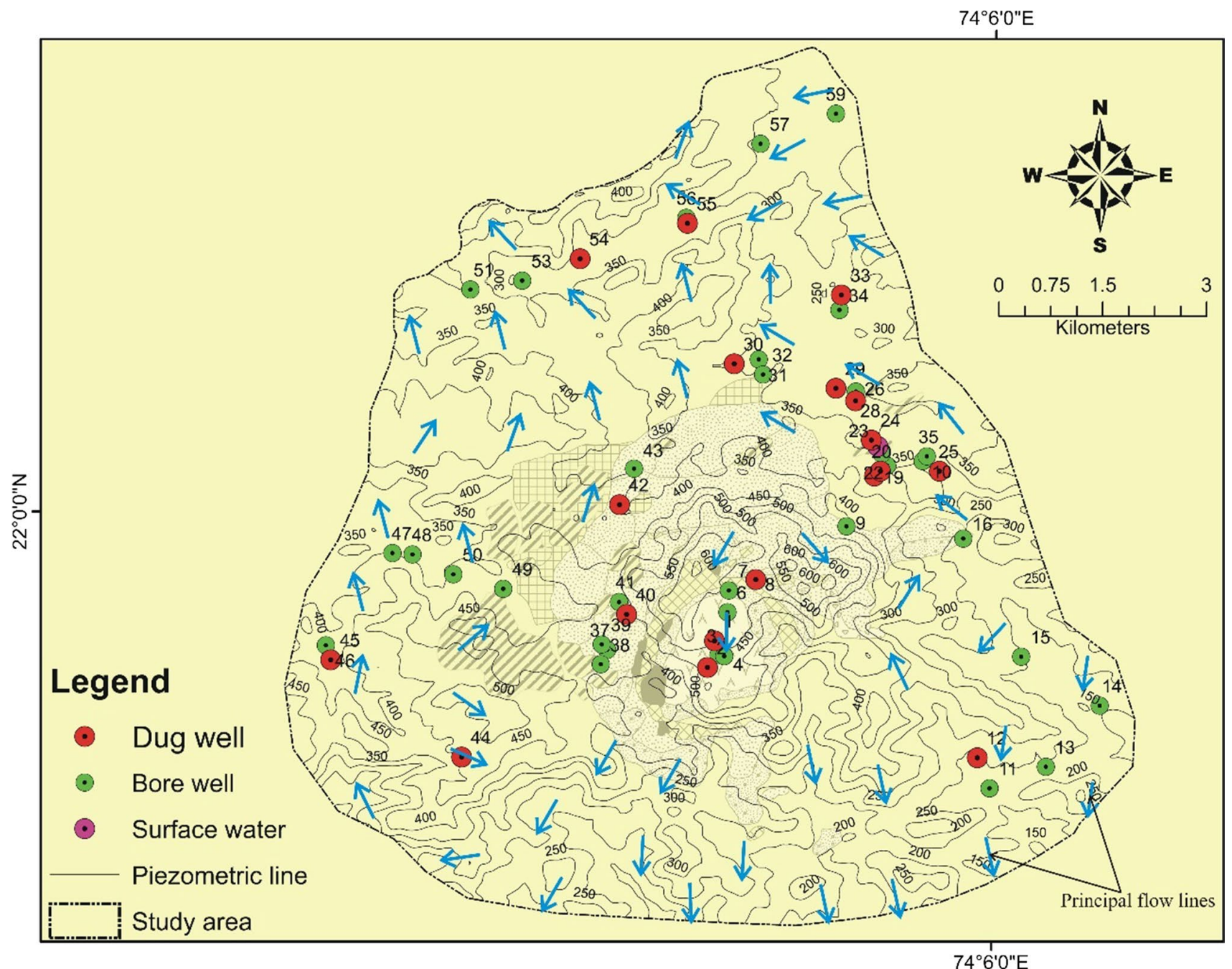

Fig. 3 Piezometric map showing sampling location

$A D D=\frac{\text { CGW } \times \text { IR } \times \mathrm{ED} \times \mathrm{EF}}{A B W \times \mathrm{AET}}$

ADD average daily dosage of fluoride and nitrate in $\mathrm{mg} /$ $\mathrm{kg} / \mathrm{d}$; CGW content of a fluoride and nitrate in groundwater $(\mathrm{mg} / \mathrm{L})$.

$\mathrm{IR}=$ ingestion rate of person in litres per day $(\mathrm{L} / \mathrm{d})$, According to USEPA (2014), the IR values of adults is 2.5 $\mathrm{L} / \mathrm{d}$ while for children it is $0.78 \mathrm{~L} / \mathrm{d}$. The exposure duration (ED) is the time duration for which the contacts happen between groundwater and person time in years. The ED value used for adults is 70 years and for children 6 years (Narsimha and Rajitha 2018). EF is the exposure frequency is the ratio of ED by the time period in which the dose is to be averaged it is considered as 365 days/year for adults and children. ABW stands for average body weight of an individual in kilogram $(\mathrm{kg})$. ABW is considered as $65 \mathrm{~kg}$ and $15 \mathrm{~kg}$ for adult and children, respectively. AET means average exposure time is the multiplication of exposure duration to exposure frequency the values are 25,550 and 2190 days for adult and children, respectively.

The reference dose (Rfd) is used as a measure for noncancer-causing prolonged hazards arises by $\mathrm{NO}_{3}$ and $\mathrm{F}$. The reference dosage is assessed to determine the risk assessments of populations in the study area that happens to be disadvantaged of a considerable risk of harmful effects during a lifetime. The harmful effects are likely to arise after the reference dosage lower than the exposure dose of the pollutant, also called as hazard quotient (HQ). The HQ is ratio of ADD divided by RFD. Where, $\mathrm{RfD}$ values for $\mathrm{NO}_{3}$ and $\mathrm{F}$ is 1.6 and $0.06 \mathrm{mg} / \mathrm{kg} / \mathrm{d}$ correspondingly (USEPA 2014). While, the Total Hazard Index (THI) of non-carcinogenic risk is calculated using following Eq. (3), Where the THI is summation of $\mathrm{HQ}_{\mathrm{F}}$ and $\mathrm{HQ}_{\mathrm{NO} 3}$ for adult and children separately (Table 3 ). 
$\mathrm{THI}=\mathrm{HQ}_{\text {nitrate }}+\mathrm{HQ}_{\text {fluoride }}$

The non-carcinogenic effects are determined if the value is less than one $(\mathrm{THI}<1)$. Though, in the case of THI value that exceeds one (THI $>1)$, inhabitants are exposed to noncarcinogenic risk (Li et al. 2016a, b; US EPA 1989, 2001).

\section{Results and discussion}

The result and discussion section is divided into three parts (1) Geochemistry of Surface water (2) geochemistry of groundwater (3) Health risk assessment.

\section{Geochemistry of surface water}

The surface water samples were collected from flowing streams. The $\mathrm{pH}$ of sample is both season is above 7 is slightly alkaline. The electrical conductivity (EC) values are below the WHO (2011) desirable limit of $500 \mu \mathrm{S} / \mathrm{cm}$ in post-monsoon season, while it is above the in pre-monsoon $(881 \mu \mathrm{S} / \mathrm{cm})$, similar trend is found for TDS. The calcium $\left(\mathrm{Ca}^{2+}\right)$, Magnesium $\left(\mathrm{Mg}^{2+}\right)$, Sodium $\left(\mathrm{Na}^{+}\right)$and potassium $\left(\mathrm{K}^{+}\right)$concentration is well below desirable limit of WHO 2011 (Table 1) for both seasons.

The bicarbonate $\left(\mathrm{HCO}_{3}{ }^{-}\right)$concentration is above the desirable limit of $200 \mathrm{mg} / \mathrm{L}$ in both pre and post-monsoon season for surface water sample. The concentration of Chloride $\left(\mathrm{Cl}^{-}\right)$, sulphate $\left(\mathrm{SO}_{4}{ }^{2-}\right)$, Nitrate $\left(\mathrm{NO}_{3}{ }^{-}\right)$and fluoride $\left(\mathrm{F}^{-}\right)$are well below desirable limit WHO 2011 (Table 1) for both seasons. The overall quality of surface water sample is good of drinking purpose.

\section{Geochemistry of groundwater}

The geochemistry of groundwater shows that $\mathrm{pH}$ of sample varies from 6.74 to 8.12 with an average of 7.36 in POM and 7.30 to 8.50 with an average of 7.70 in PRM season. The groundwaters have recorded moderate increase in $\mathrm{pH}$ from post- to pre-monsoon, indicating enhanced rock-water interaction by dissolving carbonate in water (Magesh et al. 2017). The electrical conductivity (EC) values are varying from 360 to $2170 \mu \mathrm{S} / \mathrm{cm}$ for POM and 658 to $2250 \mu \mathrm{S} / \mathrm{cm}$ for PRM season, suggesting dilution reduces the EC of groundwater. The recharge after the monsoon from rainwater reduced the $\mathrm{EC}$, which can be seen by reduction in per cent unsuitable water (Bahrami et al. 2020) The result shows that $84 \%$ and $100 \%$ samples in POM and PRM season, respectively, having values higher than desirable limit of EC (WHO 2011), whereas only one sample is above permissible limit. The TDS is a representative of total major cation and anion concentrations and ranges from 413.80 to $1048.60 \mathrm{ppm}$ in PRM and 256.60 to $804.10 \mathrm{ppm}$ in POM. Based on TDS, 29\% and $89 \%$ of groundwater samples in POM and PRM season out of the total 54 samples, respectively, exceeded the limit suggested by WHO (2011). Higher concentration of TDS in the samples is plausibly due to the ooze of salts from the host rock and certain anthropogenic activities like mining and agriculture in the study area.

The range of calcium $\left(\mathrm{Ca}^{2+}\right)$ concentration in groundwater is dependent on the solubility of $\mathrm{CaCO}_{3}$ and silicates in

Table 1 Descriptive statistics and comparison of physicochemical analysis with WHO (2011) limit of the study area during post- and pre-monsoon seasons

\begin{tabular}{|c|c|c|c|c|c|c|c|c|c|c|c|c|}
\hline \multirow[t]{2}{*}{ Parameters } & \multicolumn{2}{|c|}{ WHO limit } & \multicolumn{5}{|c|}{ Post-monsoon } & \multicolumn{5}{|c|}{ Pre-monsoon } \\
\hline & DL & PL & Min & $\operatorname{Max}$ & Avg. & $\begin{array}{l}\text { \% Sample } \\
\text { above DL }\end{array}$ & $\begin{array}{l}\% \text { Sample } \\
\text { above PL }\end{array}$ & Min & Max & Avg. & $\begin{array}{l}\text { \% Sample } \\
\text { above DL }\end{array}$ & $\begin{array}{l}\text { \% Sample } \\
\text { above PL }\end{array}$ \\
\hline $\mathrm{pH}$ & $6.5-8.5$ & - & 6.74 & 8.12 & 7.32 & 0 & 0 & 7.30 & 8.50 & 7.73 & 0 & 0 \\
\hline $\mathrm{EC}$ & 500 & 1500 & 360.00 & 2170.00 & 704.04 & 84 & 2 & 658.00 & 2250.00 & 948.88 & 100 & 2 \\
\hline TDS & 500 & 1500 & 256.60 & 804.10 & 433.06 & 29 & 0 & 413.80 & 1048.60 & 644.99 & 89 & 0 \\
\hline $\mathrm{Ca}^{++}$ & 75 & 200 & 12.00 & 108.00 & 51.66 & 25 & 0 & 17.40 & 119.00 & 71.17 & 48 & 0 \\
\hline $\mathrm{Mg}^{++}$ & 50 & 100 & 8.00 & 47.00 & 20.07 & 0 & 0 & 0.20 & 50.00 & 15.89 & 0 & 0 \\
\hline $\mathrm{Na}^{+}$ & 200 & 600 & 6.04 & 38.86 & 14.76 & 0 & 0 & 10.87 & 147.00 & 42.22 & 0 & 0 \\
\hline $\mathrm{K}^{+}$ & 10 & 12 & 0.13 & 6.42 & 2.04 & 0 & 0 & 0.09 & 1.93 & 0.42 & 0 & 0 \\
\hline $\mathrm{HCO}_{3}^{-}$ & 200 & 500 & 48.00 & 360.00 & 188.50 & 38 & 0 & 165.00 & 566.00 & 301.91 & 88 & 0 \\
\hline $\mathrm{SO}_{4}^{2-}$ & 200 & 250 & 0.10 & 48.87 & 17.46 & 0 & 0 & 0.10 & 48.06 & 16.16 & 0 & 0 \\
\hline $\mathrm{Cl}^{-}$ & 250 & 500 & 4.03 & 180.90 & 34.22 & 0 & 0 & 2.60 & 180.42 & 36.30 & 0 & 0 \\
\hline $\mathrm{NO}_{2}{ }^{2-}$ & 3 & - & 0.36 & 7.80 & 2.33 & 17 & 0 & 0.10 & 60.10 & 5.66 & 79 & 0 \\
\hline $\mathrm{NO}_{3}^{-}$ & 45 & - & 0.10 & 129.00 & 31.32 & 33 & 0 & 0.07 & 135.30 & 25.72 & 15 & 0 \\
\hline $\mathrm{F}$ & 1 & 1.5 & 0.25 & 3.35 & 1.44 & 60 & 42 & 0.43 & 4.25 & 1.42 & 63 & 40 \\
\hline
\end{tabular}

$D L$ desirable limit, $P L$ permissible limit 
rocks. The $\mathrm{Ca}^{2+}$ ion is the dominant cation of the study area as mentioned earlier. The solubility of $\mathrm{CaCO}_{3}$ depends upon the partial pressure of $\mathrm{CO}_{2}$ in the atmosphere (Pawar 1993). The $\mathrm{Ca}^{2+}$ values in groundwater range from 12 to $108 \mathrm{ppm}$ with an average of $52.53 \mathrm{ppm}$ during POM and $17.4 \mathrm{ppm}$ to $119 \mathrm{ppm}$ with an average of $71.4 \mathrm{ppm}$ in PRM suggesting contribution from carbonatites. Based on the desirable limits of $75 \mathrm{mg} / \mathrm{L}$ of WHO 2011, 25\% in POM and $48 \%$ in PRM samples exceed limit. Magnesium $\left(\mathrm{Mg}^{2+)}\right.$ has a common source as that of $\mathrm{Ca}^{2+}$; and it can be derived from $\mathrm{Mg}^{2+}$ bearing minerals like olivine, augite, biotite, hornblende, serpentine and talc. Thus, $25 \%$ of the groundwater samples in POM and almost double i.e. $48 \%$ samples in PRM period are above WHO (2011) desirable limit of $75 \mathrm{mg} / \mathrm{L}$ (Table 1). $\mathrm{Mg}^{2+}$ values in groundwater are moderate to low varying from 8 to $47 \mathrm{ppm}$ with an average of $20.2 \mathrm{ppm}$ in post-monsoon and varying concentration of $\mathrm{Mg}^{2+}$ from 0.2 to $50 \mathrm{ppm}$ with an average of $15.5 \mathrm{ppm}$ is seen in pre-monsoon. $\mathrm{Mg}^{2+}$ may also be derived from the carbonate and silicate weathering. The groundwater of the study area is normally fit for consumption purpose with respect to magnesium. Sodium values vary from 6.04 to $43.04 \mathrm{ppm}$ with an average of $14.5 \mathrm{ppm}$ in POM and $9.56 \mathrm{ppm}$ to $163.4 \mathrm{ppm}$ with an average of $43 \mathrm{ppm}$ in PRM. The increase in concentration of Sodium $\left(\mathrm{Na}^{+}\right)$in pre-monsoon is due to enhanced rock-water interaction. Elevated content of $\mathrm{Na}^{+}$is observed in the eastern part of the study area indicating the effect host-rock reaction. A high value of $\mathrm{Na}^{+}$indicates the high weathering rate (Vetrimurugan and Elango 2015a, b). The natural sources of $\mathrm{Na}^{+}$include nepheline, sodalite, glaucophane, aegirine, etc. that are not wide spread like calcium and magnesium bearing minerals. Very small potassium $\left(\mathrm{K}^{+}\right)$concentration is seen in study area, as it varies from 0.13 to $6.42 \mathrm{ppm}$ with an average of $2 \mathrm{ppm}$ in post-monsoon and $0.06 \mathrm{ppm}$ to $1.93 \mathrm{ppm}$ with an average of $0.4 \mathrm{ppm}$. Potassium level in can be reduced by the use of treatment process by activated carbon method. The natural geological sources of $\mathrm{K}^{+}$are silicate (Pawar et al. 2008).

Geology in study area comprises of carbonate rich rocks, carbonate is the main and abundant anion in the study area in both seasons. The Bicarbonate $\left(\mathrm{HCO}_{3}{ }^{-}\right)$concentration varies from 48 to $360 \mathrm{ppm}$ with an average of $188.50 \mathrm{ppm}$ in POM and in PRM it varies from 44 to $179.2 \mathrm{ppm}$ with an average of $83.6 \mathrm{ppm}$. Bicarbonate is the most important and abundant anion in study area. Bicarbonate is the principal anion varying from 48 to $360 \mathrm{ppm}$ with an average of 188.50 ppm in POM and 165 ppm to 566 ppm with an average of $301.91 \mathrm{ppm}$ in PRM. The main sources of it could be weathering reactions with silicate and carbonate minerals present in the aquifer lithology giving rise to $\mathrm{HCO}_{3}{ }^{-}$. Above $\mathrm{pH} 4.3$ carbonates get converted into bicarbonate ions. In the present area the $\mathrm{pH}$ values range from 6.74 to 8.12 in post-monsoon and 7.3 to 8.5 in pre-monsoon, indicating carbonate species exist in the form of bicarbonate ions. The comparison of WHO standard desirable limit of (200 ppm), the POM season shows about $38 \%$ and PRM season $88 \%$ sample above limit. Sulphate $\left(\mathrm{SO}_{4}{ }^{2-}\right)$ is generally dispersed in reduced state in different rocks as metallic sulphide and it is not a main component of the earth's external shell. The sulphate varies from not detected $0.10 \mathrm{ppm}$ to $48.87 \mathrm{ppm}$ in post-monsoon and $0.1 \mathrm{ppm}$ to $48.06 \mathrm{ppm}$ in pre-monsoon. $\mathrm{SO}_{4}{ }^{2-}$ content in study region is affected by the farming practices, since the chemical manures are used for enhancing the nutrient contents of soil. The major sources of $\mathrm{SO}_{4}{ }^{2-}$ in groundwater are rainwater, sulphur minerals and sulphides of heavy metals from igneous and metamorphic rocks (Brindha and Elango 2014). The chloride is obtained as minor constituent in rocks. In present study area the concentration varies from 4.03 to $180.90 \mathrm{ppm}$ in post-monsoon which might be from sources other than natural. The concentration of $\mathrm{Cl}$ varies from 2.6 to $180.42 \mathrm{ppm}$ with an average of $36.8 \mathrm{ppm}$ in pre-monsoon. In cultivated fields, around fifty to seventy-five percentage of water used is consumed by evapotranspiration and the residual portion penetrates and joins the subsurface water. The penetration of water into subsurface will have elevated salinity because of vaporisation and evapotranspiration, and therefore upsurges the groundwater salinity (Vetrimurugan and Elango 2015a, b).

Nitrate geochemistry: In general, $\mathrm{NO}_{3}{ }^{-}$concentration above $45 \mathrm{ppm}$ is outcome of anthropogenic actions (Pawar and Shaikh 1995). The nitrate $\left(\mathrm{NO}_{3}{ }^{-}\right)$ion is the maximum reacted form of nitrogen in environment and is comparatively non-toxic to amphibian (Vetrimurugan and Elango $2015 \mathrm{a}, \mathrm{b})$. Though, the content of $\mathrm{NO}_{3}{ }^{-}$turn into too much alongside with phosphate, results into eutrophication as main ecological problem. Nitrate pollution in groundwater from irrigated crop land is strongly associated with agricultural fertilizers used (Suthar et al. 2009; Fabro et al. 2015). Out of $100 \%$ applied $\mathrm{N}$ fertiliser only half is used for plant and agricultural activity, rest is remaining in soil. The half of $\mathrm{N}-\mathrm{NO}_{3}$ will remain in soil or released and converted in other form by the process such as leaching, denitrification, and volatilisation (Lawniczak et al. 2016). The nitrate values vary from 0.10 to $129 \mathrm{ppm}$ with an average of $31.32 \mathrm{ppm}$ in post-monsoon and 0.07 to $135.3 \mathrm{ppm}$ with an average of 25.72 in pre-monsoon. The POM is having 33\% and PRM is having $15 \%$ samples above WHO desirable limit of $45 \mathrm{ppm}$. The high concentration of nitrate in post-monsoon may be contributed by the irrigated return flow due to high agricultural activities. But in pre-monsoon the contribution of nitrate may be due to both lithogenic and anthropogenic inputs (Brindha et al. 2017b). The groundwater is unfit for drinking with respect to the concentration of $\mathrm{NO}_{3}{ }^{-}$at few locations in southwestern part of the area (Fig. 4a, b). The change in the content of $\mathrm{NO}_{3}{ }^{-}$with depth of wells shows the effect of use of manures, such as ammonium chloride, 


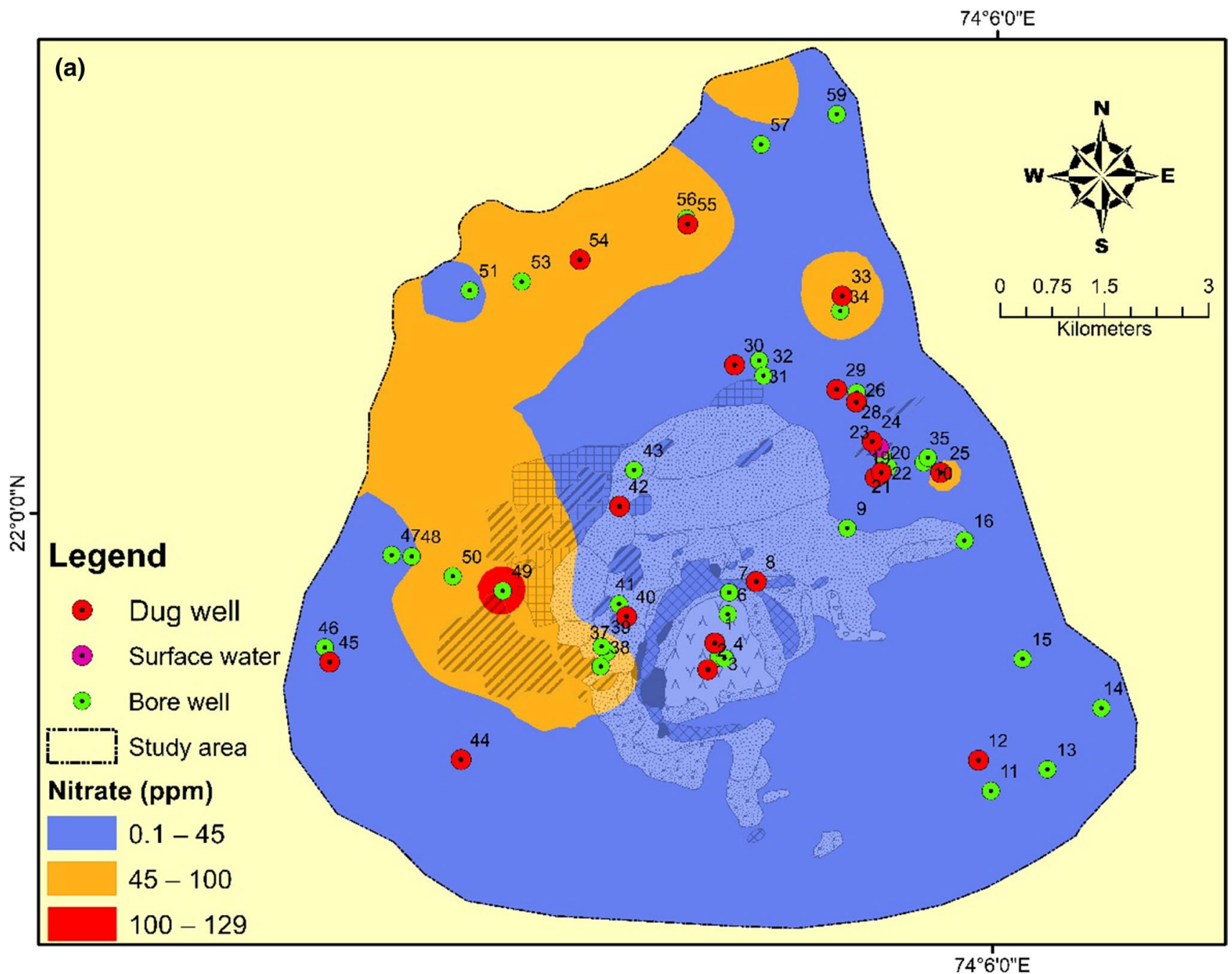

Fig. 4 a Nitrate distribution map in POM 2014. b Nitrate distribution map in PRM 2015

muriate of potash in agricultural field upsurges $\mathrm{KNO}_{3}$ in surface and subsurface water. That is the content of $\mathrm{NO}_{3}{ }^{-}$in subsurface water from the upper part of the aquifer is comparatively high.

Fluoride geochemistry: The hydrochemical data for fluoride in post-monsoon shows higher values than the permissible limit with minimum concentration of $0.25 \mathrm{ppm}$ to $5.11 \mathrm{ppm}$ having an average of $1.30 \mathrm{ppm}$ in post-monsoon and varying concentration of $0.43 \mathrm{ppm}$ to $4.25 \mathrm{ppm}$ with an average of $1.5 \mathrm{ppm}$ in pre-monsoon. Thus, the subsurface water of this area is unfit for domestic use, based on the concentration of fluoride. The spatial dispersal of fluoride content in subsurface water of this area is shown in Fig. 4a, b. The concentration of fluoride in study area was classified into four classes based on the BIS standards as less than permissible limit $<0.6$, within limit $0.6-1.25$, greater than limit 1.25-2.25, and excess $>2.25$.
In post-monsoon the analysis shows that about $17 \%$ of the samples 7 bore wells and 4 dug wells show excess concentration of $\mathrm{F}$ in ground water, the geology predominantly here is nepheline, limestones and sandstones. The $32 \%$ of samples show $\mathrm{F}$ concentration greater than the permissible limit, geology here is prominently basaltic, nepheline and at some place's limestone. The $40 \%$ samples are within limit (i.e. $0.6 \mathrm{ppm}$ to $1.25 \mathrm{ppm}$ ) (Fig. 5a) these samples belong to the area around carbonatite complex with geology soviet, ankerite, carbonatite breccia and basalt. About $11 \%$ of samples (6 bore wells and 1) surface water show less concentration of fluoride than required, these samples also belong to the area of basaltic geology. Most of the higher concentration of the $\mathrm{F}$ is seen in Bore wells as compared to the dug wells. Highest concentration of $\mathrm{F}$ is seen in dug well which is close to the nephelinite plug, also many samples in and around nepheline plug show greater to excess concentration of $\mathrm{F}$. 


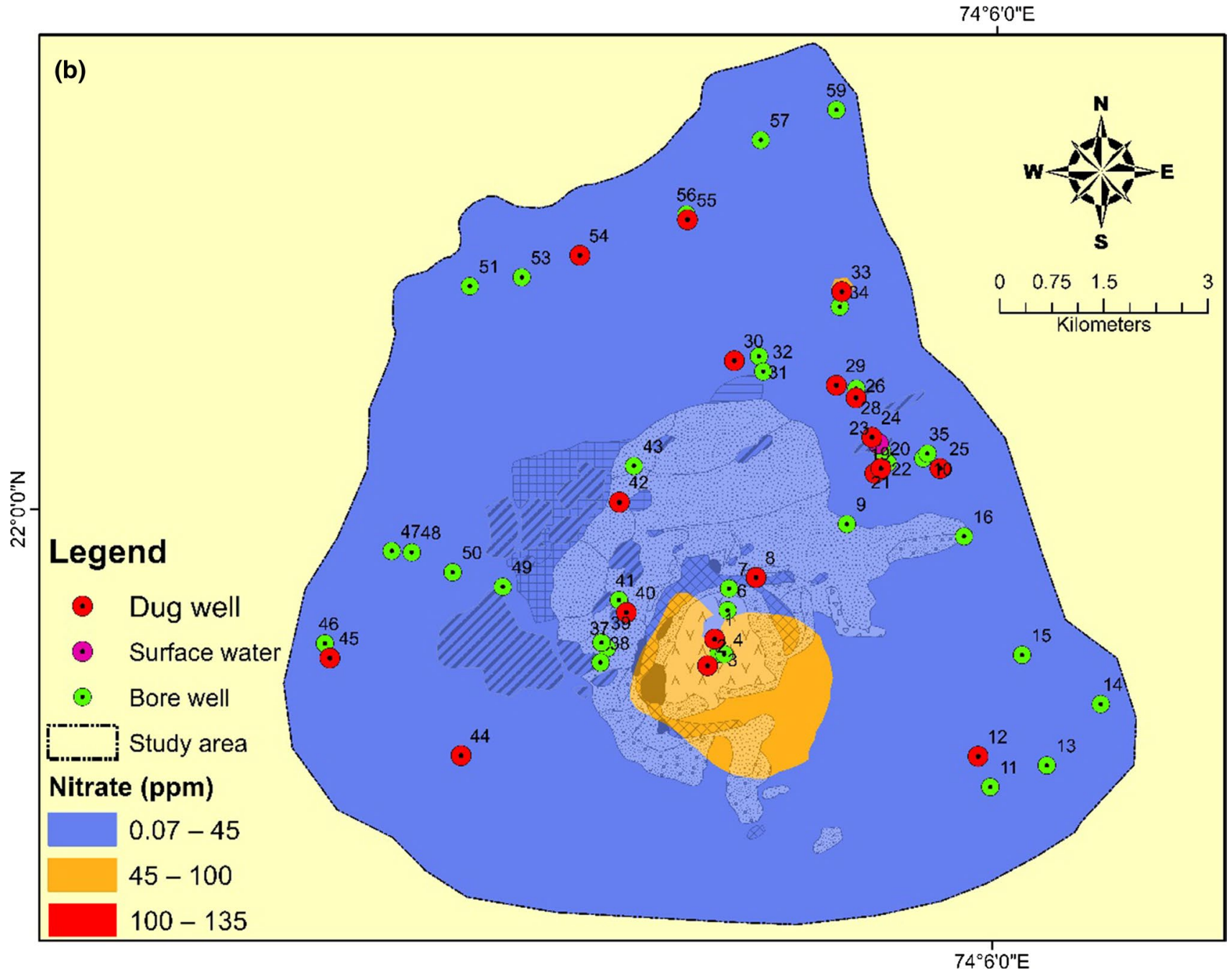

Fig. 4 (continued)

In pre-monsoon about $12 \%$ of the samples belong to the class of excess concentration of $\mathrm{F}$. The higher concentration of $\mathrm{F}$ is seen in dug wells which are present in basalt and single sample belong to limestone and nephelinite aquifer. Forty-three per cent of the samples show values of $\mathrm{F}$ greater than permissible limit (18 bore well samples and 8 dug well samples) having lithology of basalt, nephelinite and limestone. Thirty-eight per cent of the samples show higher F concentration than the permissible limit which is the area in and around the carbonatite ring complex. Seven per cent of the samples shows the concentration of $\mathrm{F}$ less then permissible limit that are from basaltic aquifer as seen in sample no's $17,22,27-31,33-35,40,44-46$, areas having lithology basalt, limestone and sandstones. The maximum value of fluoride $(5.11 \mathrm{ppm})$ in sample no. 1 is from carbonatite breccia, similarly, higher values ranging from 4 to $7 \mathrm{ppm}$ are seen in this area having carbonatite basalt, sovite and ankerite lithology, with an average value of 1.84 ppm (Fig. 5b).
Piper plot: To categorise and differentiate the groundwater on the basis of its chemical composition the Piper's trilinear diagram was used (Piper 1953) (Fig. 6a, b). This is helpful to know the total element character of waters in terms of cations and anions composition. The Piper's plot for POM (Fig. 5a) shows that the $\mathrm{Ca}^{2+}$ and $\mathrm{HCO}_{3}{ }^{-}$as the main cations and anions, respectively. Most of the samples show cation $\mathrm{Ca}^{2+}+\mathrm{Mg}^{2+}$ as dominant facies and $\mathrm{HCO}_{3}{ }^{-}$as anion dominant facies in the post-monsoon season. Water type here shows dominance of $\mathrm{Ca}-\mathrm{HCO}_{3}$ wherein about $68 \%$ of the samples belong to this category, $19 \%$ of the samples show $\mathrm{Mg}-\mathrm{HCO}_{3}$ type, $8 \% \mathrm{Ca}-\mathrm{Cl}$ type, $3 \% \mathrm{Mg}-\mathrm{Cl}$ type and only $2 \%$ show $\mathrm{Na}-\mathrm{HCO}_{3}{ }^{-}$type.

The pre-monsoon (Fig. 5b) samples show that the study area has $\mathrm{Ca}^{2+}, \mathrm{Na}^{+}, \mathrm{Mg}^{2+}$ and $\mathrm{HCO}_{3}{ }^{-}$as the predominant cations and anions, respectively. Most of the samples from the area fall in the category of $\mathrm{Ca}-\mathrm{HCO}_{3}{ }^{-}$type of water (72\%), $21 \%$ of the samples show $\mathrm{Na}-\mathrm{HCO} 3$ type of water, 


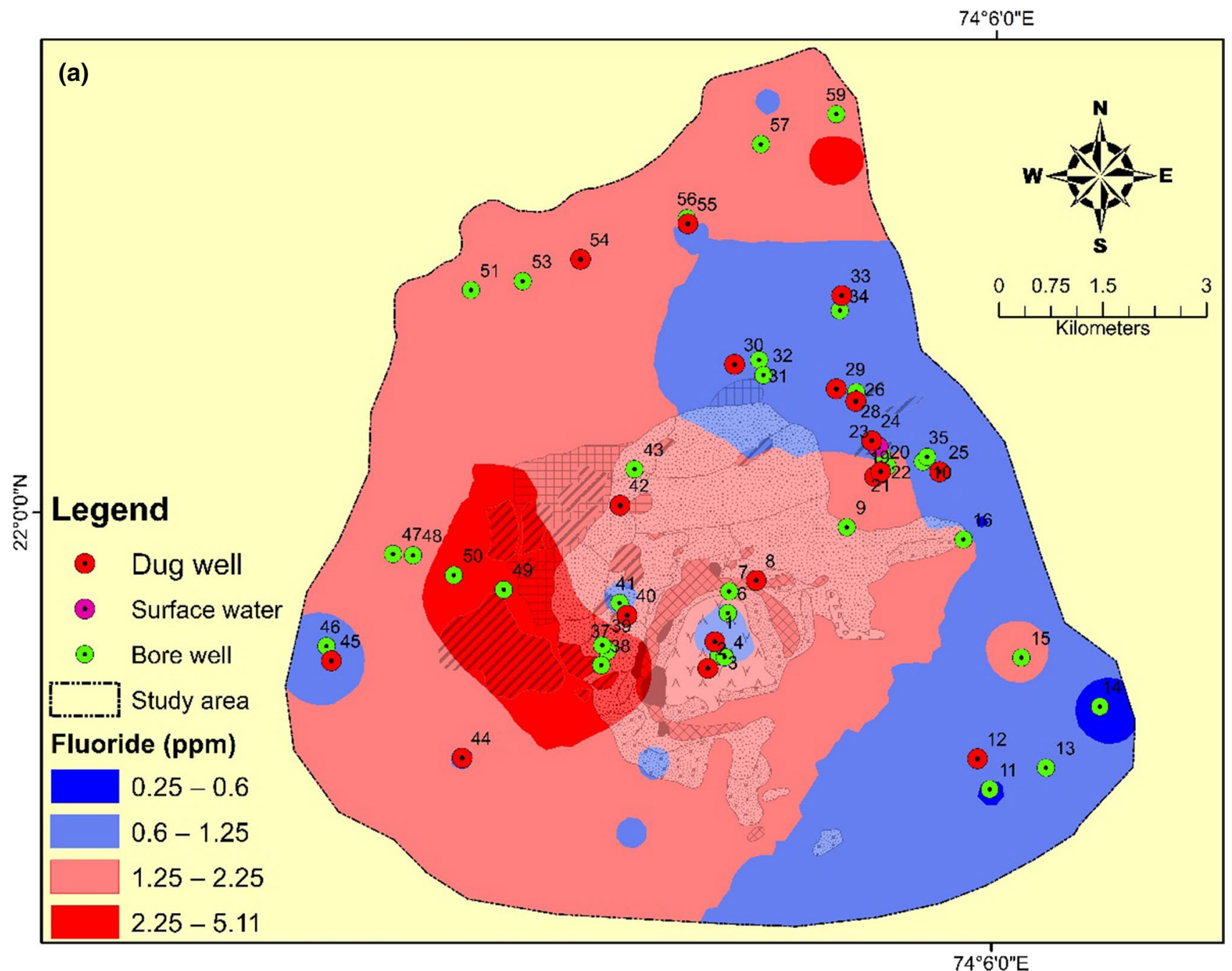

Fig. 5 a Fluoride distribution map in POM 2014. b Fluoride distribution map in PRM 2015

$5 \%$ shows $\mathrm{Mg}-\mathrm{HCO}_{3}{ }^{-}$type and remaining one sample show $\mathrm{Ca}-\mathrm{Cl}$ water type. The presence of carbonate and bicarbonate facies may be dictated by weathering of carbonate and silicate rocks in study area, which is further confirmed by Gibbs plot.

Gibbs plot: Gibbs (1970) identified three different mechanisms that control the composition of water. The plot of $(\mathrm{Na}+\mathrm{K} / \mathrm{Na}+\mathrm{k}+\mathrm{Ca}$ ) Vs. TDS (Fig. $6 \mathrm{a}$, $\mathrm{b}$ for post-monsoon and pre-monsoon, respectively) illustrates these mechanisms. To understand the genesis of $\mathrm{F}$ in groundwater, it is essential to study interaction of water with the aquifer minerals. Gibbs plot gives an idea about the reactions bringing changes in water chemistry. Almost all the groundwater samples in post-monsoon from the study area represent the water rock interaction that is primarily controlling the major ion chemistry in general and fluoride in particular of groundwater in this region (Fig. 7a) but in pre-monsoon some of the samples BW34, BW16, BW49, BW92, BW 112 show the evaporation-precipitation dominance, remaining all shows rock dominance (Fig. 7b). From this arrangement, it is confirmed that most of the groundwater samples from vicinity of rock shows the rock dominance in both seasons.

\section{Health risk assessment}

The qualitative estimation of fluoride and nitrate suggest that few samples surpass the threshold limit of B and F drinking standards. The non-carcinogenic health risk of fluoride and nitrate was calculated for different age groups of children and adults based on USEPA standards. Initially, ADD is computed for children and adults. Further, the health risks for children and adults were calculated by considering the ADD, CCGW, IR ED, etc. The $\mathrm{HQ}_{\mathrm{NO} 3}$ and $\mathrm{HQ}_{\mathrm{F}}$ of adults for POM range between 0.002 to 3.10 and 0.16 to 2.15 with an average of 0.78 and 0.93 , respectively (Table 2). For children, the $\mathrm{HQ}_{\mathrm{NO} 3}$ and $\mathrm{HQ}_{\mathrm{F}}$ by consumption of groundwater 


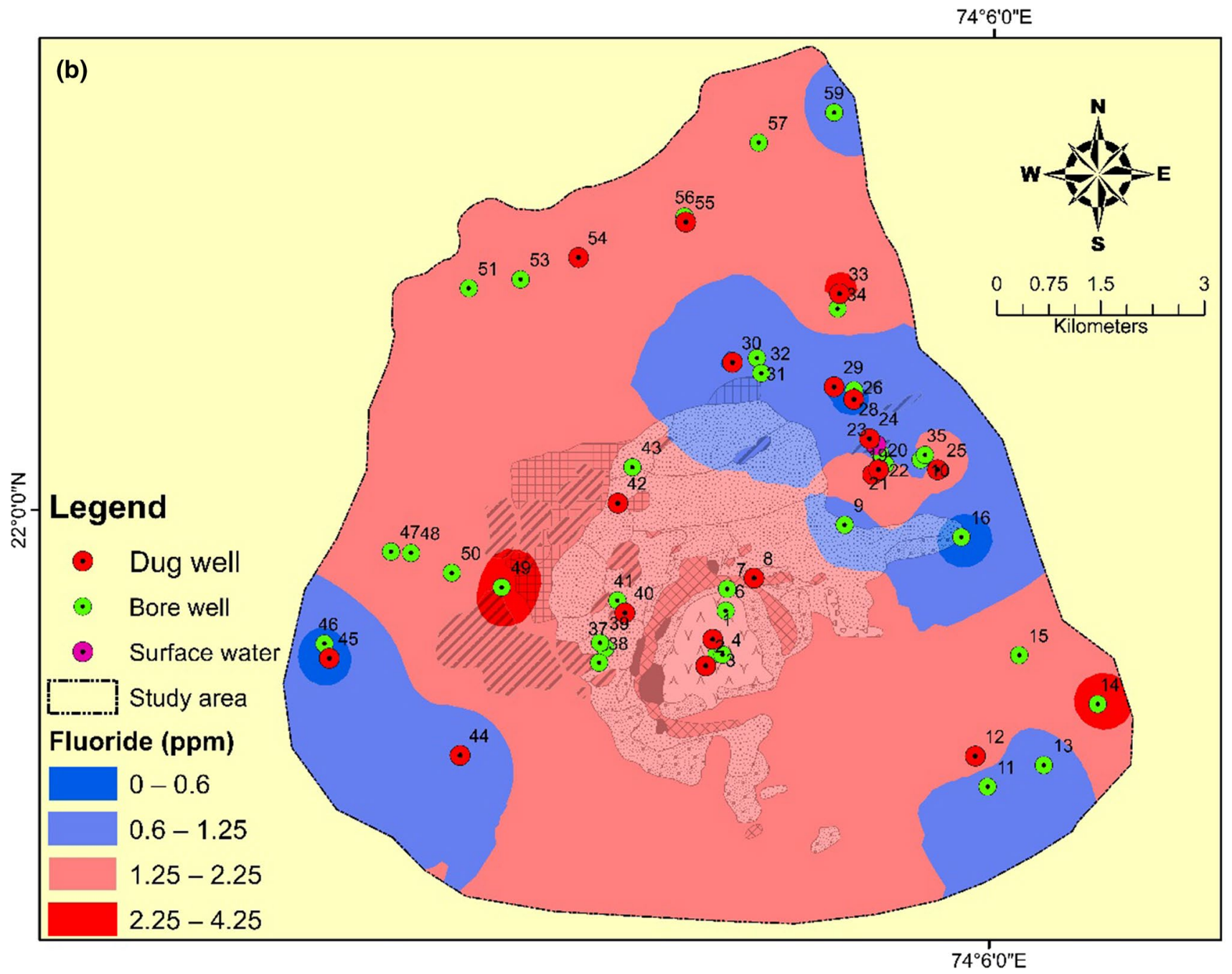

Fig. 5 (continued)

vary between 0.03 and 4.19 and from 0.22 to 2.90 , respectively for POM (Table 2). The HQNO3 and HQF of adults for POM vary from 0.002 to 3.10 and from 0.16 to 2.15 with an average of 0.78 and 0.93 , respectively (Table 3 ).

According to USEPA health risk assessment standards, the permissible limit of non-carcinogenic THI is 1 . If THI is $>1$, then it shows the non-carcinogenic risk; while, if the THI is $<1$ then within the acceptable limit (USEPA 2014). The $58.85 \%$ and $44.23 \%$ of samples have the HQ value for fluoride and nitrate than the tolerable limit, signifying that fluoride contributes more to the non-carcinogenic risk than nitrate for adults and children. The PRM season shows $38.46 \%$ and $55.77 \%$ fluoride hazard quotients for adults and children. While nitrate is having low hazard quotients of $21.15 \%$ and $26.92 \%$ for adult and children, respectively. This also recommends that consumption of fluoride contaminated well water can cause more health risks than the nitrate. THI is the sum of HQ of nitrate and fluoride. As shown in Table 2 and 3, the THI of nitrate and fluoride for post-monsoon season ranged from 0.17 to 4.94 with an average of 1.71 for adults, while for pre-monsoon it is ranges from 0.34 to 4.14 with average of 1.56. For children the post-monsoon THI values ranges from 0.18 to 6.03 with the average of 1.98 and for post-monsoon it is varies from 0.46 to 5.60 with a mean of 2.11 for pre-monsoon (Fig. 8a, b). The THI value is greater than 1 in $65.4 \%$ and $71.2 \%$ sample locations for adult in POM and PRM season, respectively. While THI value greater than 1 for children is $71.2 \%$ and $82.7 \%$ sample locations in POM and PRM season, respectively (Fig. 9). The outcomes are revealing that children are more prone to non-carcinogenic risk as compare with adults. Similar study results were found in various area of the world such as Nirmal Province, South India (Adimalla et al. 2019), Kurdistan County, Iran (Rezaei et al. 2019), and northwest China (Chen et al. 2017); they revealed that the children are having high risk due to lesser body masses than Adult. This could 
(a)

Piper Diagram (Post Monsoon 2014)

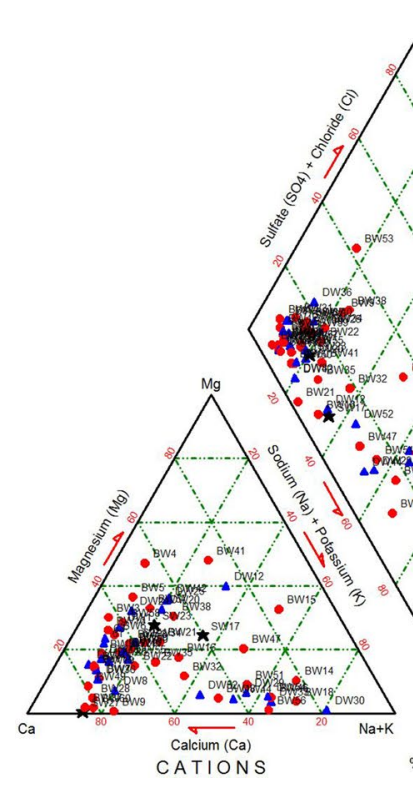

(b)

Piper Diagram (Pre Monsoon 2014)

Fig. 6 a Hydrochemical facies of the groundwater samples in POM 2014. b Hydrochemical facies of the groundwater samples in PRM 2015

\section{(a)}

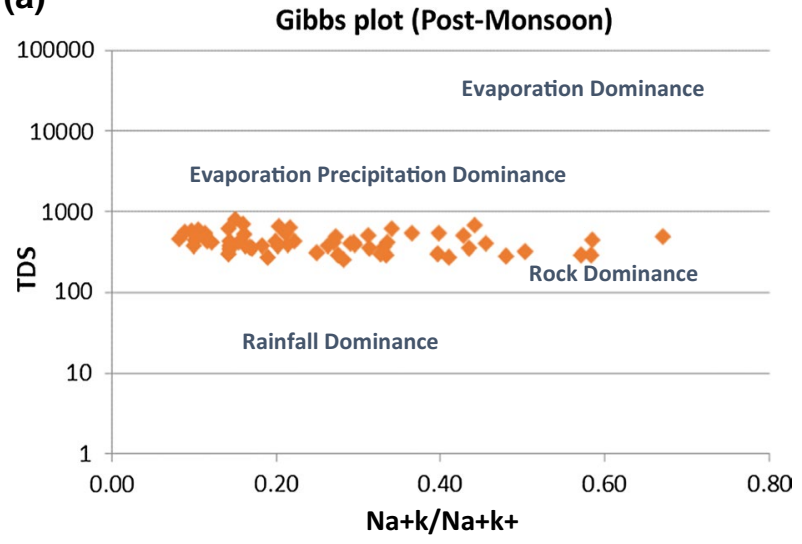

(b)

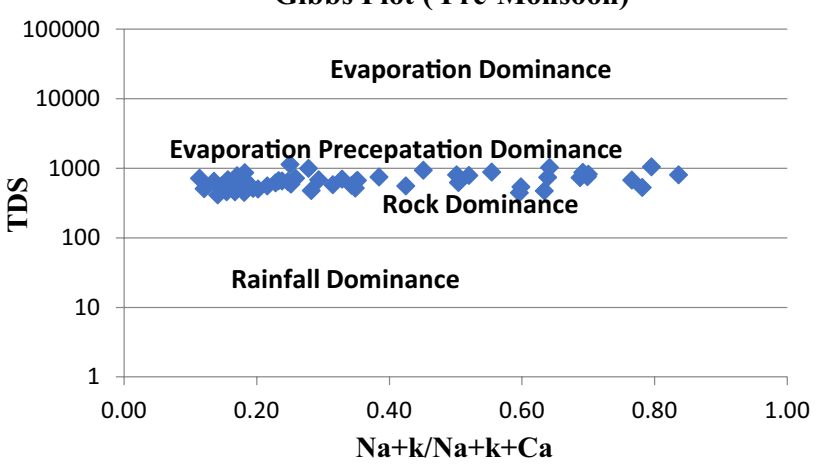

Fig. 7 a Gibbs plot of POM 2014. b Gibbs plot of PRM 2015 be the cause that children are affected more fluorosis health risks in India. Consumption of extremely polluted water, with admiration to fluoride and nitrate, is the probable cause for health risk in the area under investigation. Higher content of $\mathrm{F}$ and $\mathrm{NO}_{3}{ }^{-}$in subsurface water extremely associates with human health risks such as high nitrate concentration, above $100 \mathrm{mg} / \mathrm{l}$, is an important cause of methaemoglobinaemia formation and gastric and/or oesophageal cancer exposed inhabitants (Adimalla et al. 2019), in addition to fluorosis of teeth and bones, diseases associated with thyroid, nervous system (neurophysiological disorders), digestion system (liver) and memory loss can occur (Lu et al. 2000; Ayoob and Gupta 2006).

In study area for healthier life, protection of waters is the utmost effective method of safeguarding domestic water security. Spreading of manures in the correct quantity, at the exact period of year, and through the correct method may be helpful to groundwater protection. Irrigation schemes with better productivity, such as drips and sprinklers, should be endorsed and spread. Additionally, distributed water supply schemes are practicable to increase the ingestion water quality in study area, which can assist only one village with one scheme. Additional, groundwater observing system should be prepared as early as possible. The groundwater reserve can be used judicially, and pollutants can be identified and measured and removed at source of supply. The water quality analysis data can be helpful to offer additional data on domestic water security with the associated consumers. These outcomes of study can be helpful for providing 
Table 2 Average daily dose (ADD) hazard quotient (HQ) and total hazard index (THI) for adults and children in the study area for post-monsoon season

\begin{tabular}{|c|c|c|c|c|c|c|c|c|c|c|}
\hline \multirow[b]{2}{*}{ Sample no } & \multicolumn{5}{|l|}{ Adult } & \multicolumn{5}{|l|}{ Children } \\
\hline & ADD Fluoride & ADD Nitrate & HQ Fluoride & HQ Nitrate & THI & ADD Fluoride & ADD Nitrate & HQ Fluoride & HQ Nitrate & THI \\
\hline DW1 & 0.03 & 2.02 & 0.42 & 1.26 & 1.68 & 0.034 & 2.73 & 0.57 & 1.71 & 2.13 \\
\hline DW2 & 0.10 & 2.34 & 1.69 & 1.46 & 3.15 & 0.137 & 3.16 & 2.29 & 1.98 & 3.67 \\
\hline BW3 & 0.01 & 0.23 & 0.16 & 0.14 & 0.30 & 0.013 & 0.31 & 0.22 & 0.19 & 0.35 \\
\hline BW4 & 0.04 & 0.19 & 0.63 & 0.12 & 0.74 & 0.051 & 0.25 & 0.85 & 0.16 & 0.79 \\
\hline BW6 & 0.03 & 0.54 & 0.54 & 0.34 & 0.88 & 0.044 & 0.73 & 0.73 & 0.46 & 1.00 \\
\hline BW7 & 0.08 & 1.52 & 1.32 & 0.95 & 2.27 & 0.107 & 2.05 & 1.79 & 1.28 & 2.60 \\
\hline DW8 & 0.09 & 0.85 & 1.53 & 0.53 & 2.06 & 0.124 & 1.14 & 2.07 & 0.71 & 2.25 \\
\hline BW9 & 0.08 & 0.01 & 1.41 & 0.01 & 1.42 & 0.114 & 0.01 & 1.91 & 0.01 & 1.42 \\
\hline BW10 & 0.02 & 0.71 & 0.37 & 0.45 & 0.81 & 0.030 & 0.97 & 0.49 & 0.60 & 0.97 \\
\hline BW11 & 0.02 & 0.52 & 0.35 & 0.33 & 0.68 & 0.029 & 0.70 & 0.48 & 0.44 & 0.79 \\
\hline DW12 & 0.03 & 0.02 & 0.54 & 0.02 & 0.56 & 0.044 & 0.03 & 0.74 & 0.02 & 0.57 \\
\hline BW13 & 0.02 & 0.11 & 0.39 & 0.07 & 0.46 & 0.032 & 0.15 & 0.53 & 0.09 & 0.48 \\
\hline BW14 & 0.02 & 0.00 & 0.30 & 0.00 & 0.30 & 0.024 & 0.01 & 0.41 & 0.00 & 0.30 \\
\hline BW15 & 0.06 & 0.04 & 0.92 & 0.03 & 0.95 & 0.075 & 0.05 & 1.25 & 0.03 & 0.96 \\
\hline BW16 & 0.06 & 0.00 & 0.99 & 0.00 & 0.99 & 0.080 & 0.01 & 1.33 & 0.00 & 0.99 \\
\hline DW19 & 0.07 & 2.09 & 1.12 & 1.31 & 2.42 & 0.090 & 2.83 & 1.51 & 1.77 & 2.89 \\
\hline DW20 & 0.08 & 1.18 & 1.31 & 0.74 & 2.05 & 0.107 & 1.60 & 1.78 & 1.00 & 2.31 \\
\hline BW21 & 0.10 & 1.44 & 1.67 & 0.90 & 2.57 & 0.135 & 1.95 & 2.25 & 1.22 & 2.88 \\
\hline BW22 & 0.02 & 0.00 & 0.31 & 0.00 & 0.32 & 0.025 & 0.01 & 0.42 & 0.00 & 0.32 \\
\hline SW23 & 0.03 & 0.32 & 0.42 & 0.20 & 0.62 & 0.034 & 0.43 & 0.57 & 0.27 & 0.69 \\
\hline DW24 & 0.04 & 0.32 & 0.71 & 0.20 & 0.90 & 0.057 & 0.43 & 0.95 & 0.27 & 0.97 \\
\hline DW25 & 0.03 & 3.15 & 0.50 & 1.97 & 2.47 & 0.041 & 4.26 & 0.68 & 2.66 & 3.16 \\
\hline DW26 & 0.05 & 1.11 & 0.91 & 0.70 & 1.61 & 0.074 & 1.50 & 1.23 & 0.94 & 1.85 \\
\hline BW28 & 0.03 & 0.94 & 0.44 & 0.59 & 1.03 & 0.035 & 1.28 & 0.59 & 0.80 & 1.23 \\
\hline DW29 & 0.04 & 1.77 & 0.58 & 1.11 & 1.69 & 0.047 & 2.40 & 0.79 & 1.50 & 2.08 \\
\hline DW30 & 0.02 & 1.10 & 0.38 & 0.69 & 1.07 & 0.031 & 1.49 & 0.52 & 0.93 & 1.32 \\
\hline BW31 & 0.03 & 0.72 & 0.43 & 0.45 & 0.88 & 0.035 & 0.97 & 0.58 & 0.61 & 1.04 \\
\hline BW32 & 0.06 & 0.32 & 0.92 & 0.20 & 1.12 & 0.075 & 0.43 & 1.25 & 0.27 & 1.19 \\
\hline DW33 & 0.04 & 2.15 & 0.62 & 1.34 & 1.96 & 0.050 & 2.90 & 0.84 & 1.81 & 2.43 \\
\hline BW34 & 0.03 & 2.65 & 0.50 & 1.66 & 2.16 & 0.041 & 3.58 & 0.68 & 2.24 & 2.74 \\
\hline BW35 & 0.04 & 0.58 & 0.60 & 0.36 & 0.97 & 0.049 & 0.79 & 0.81 & 0.49 & 1.09 \\
\hline BW37 & 0.11 & 1.89 & 1.79 & 1.18 & 2.97 & 0.145 & 2.56 & 2.42 & 1.60 & 3.39 \\
\hline BW38 & 0.13 & 2.97 & 2.15 & 1.86 & 4.00 & 0.174 & 4.01 & 2.90 & 2.51 & 4.66 \\
\hline BW39 & 0.13 & 2.57 & 2.15 & 1.60 & 3.75 & 0.174 & 3.47 & 2.90 & 2.17 & 4.32 \\
\hline DW40 & 0.06 & 0.08 & 0.97 & 0.05 & 1.03 & 0.079 & 0.11 & 1.32 & 0.07 & 1.04 \\
\hline BW41 & 0.01 & 0.02 & 0.16 & 0.01 & 0.17 & 0.013 & 0.03 & 0.22 & 0.02 & 0.18 \\
\hline DW42 & 0.07 & 1.79 & 1.16 & 1.12 & 2.28 & 0.094 & 2.42 & 1.57 & 1.51 & 2.67 \\
\hline BW43 & 0.07 & 0.11 & 1.12 & 0.07 & 1.18 & 0.090 & 0.15 & 1.51 & 0.09 & 1.21 \\
\hline DW44 & 0.05 & 0.66 & 0.76 & 0.41 & 1.17 & 0.062 & 0.89 & 1.03 & 0.56 & 1.32 \\
\hline DW45 & 0.04 & 0.35 & 0.60 & 0.22 & 0.82 & 0.049 & 0.47 & 0.81 & 0.30 & 0.90 \\
\hline BW46 & 0.04 & 0.06 & 0.65 & 0.03 & 0.69 & 0.053 & 0.07 & 0.88 & 0.05 & 0.70 \\
\hline BW47 & 0.06 & 1.25 & 1.01 & 0.78 & 1.79 & 0.082 & 1.69 & 1.36 & 1.06 & 2.06 \\
\hline BW48 & 0.07 & 1.66 & 1.10 & 1.04 & 2.14 & 0.089 & 2.24 & 1.49 & 1.40 & 2.50 \\
\hline BW49 & 0.11 & 4.96 & 1.84 & 3.10 & 4.94 & 0.149 & 6.71 & 2.49 & 4.19 & 6.03 \\
\hline BW50 & 0.12 & 3.86 & 2.03 & 2.41 & 4.44 & 0.164 & 5.22 & 2.74 & 3.26 & 5.29 \\
\hline BW51 & 0.08 & 1.44 & 1.35 & 0.90 & 2.25 & 0.110 & 1.94 & 1.83 & 1.21 & 2.57 \\
\hline BW53 & 0.08 & 2.24 & 1.39 & 1.40 & 2.79 & 0.113 & 3.02 & 1.88 & 1.89 & 3.28 \\
\hline
\end{tabular}


Table 2 (continued)

\begin{tabular}{|c|c|c|c|c|c|c|c|c|c|c|}
\hline \multirow[b]{2}{*}{ Sample no } & \multicolumn{5}{|l|}{ Adult } & \multicolumn{5}{|l|}{ Children } \\
\hline & ADD Fluoride & ADD Nitrate & HQ Fluoride & HQ Nitrate & THI & ADD Fluoride & ADD Nitrate & HQ Fluoride & HQ Nitrate & THI \\
\hline DW54 & 0.06 & 1.97 & 1.01 & 1.23 & 2.24 & 0.082 & 2.66 & 1.36 & 1.66 & 2.67 \\
\hline DW55 & 0.04 & 1.79 & 0.67 & 1.12 & 1.79 & 0.054 & 2.43 & 0.90 & 1.52 & 2.18 \\
\hline BW56 & 0.06 & 2.34 & 0.95 & 1.46 & 2.41 & 0.077 & 3.17 & 1.28 & 1.98 & 2.93 \\
\hline BW57 & 0.05 & 0.93 & 0.88 & 0.58 & 1.46 & 0.072 & 1.25 & 1.20 & 0.78 & 1.67 \\
\hline BW59 & 0.07 & 0.77 & 1.15 & 0.48 & 1.63 & 0.093 & 1.04 & 1.55 & 0.65 & 1.79 \\
\hline Min & 0.010 & 0.004 & 0.160 & 0.002 & 0.174 & 0.013 & 0.005 & 0.217 & 0.003 & 0.178 \\
\hline $\operatorname{Max}$ & 0.129 & 4.962 & 2.147 & 3.101 & 4.941 & 0.174 & 6.708 & 2.903 & 4.193 & 6.032 \\
\hline Average & 0.056 & 1.252 & 0.929 & 0.783 & 1.707 & 0.075 & 1.693 & 1.24 & 1.058 & 1.982 \\
\hline
\end{tabular}

information about domestic water security for local government officials, researcher and scientist for future work.

\section{Conclusions}

Hydrochemical analysis has been done to examine the $\mathrm{NO}_{3}{ }^{-}$and $\mathrm{F}^{-}$pollutants in groundwater and the related health risk assessment for inhabitants in study area Amba Dongar of semi-arid region, western Gujarat, India, were groundwater is the main resource for domestic use. The conclusion of study as below

1. Hydrochemical interpretation reveals that the groundwater is slightly alkaline and hard to very hard type. Analysed physicochemical parameters indicate that few of the samples are within allowable limits of the WHO limit. Moreover, parameters like EC, TDS, $\mathrm{Ca}^{2+}$, and $\mathrm{HCO}_{3}{ }^{-}$exceed the desirable limit in some sampled areas. $\mathrm{NO}_{3}{ }^{-}$and $\mathrm{F}^{-}$content surpass the recommended limit of drinking in few groundwater samples. A high content of EC and TDS was observed due to accumulation of salt and anthropogenic inputs.

2. The sequence of domination of major ions was in the order of cation $\left(\mathrm{Ca}^{2+}>\mathrm{Na}^{+}>\mathrm{Mg}^{2+}>\mathrm{K}^{+}\right.$and anion $\left(\mathrm{HCO}_{3}{ }^{-}>\mathrm{Cl}^{-}>\mathrm{SO}_{4}{ }^{2-}>\mathrm{NO}_{3}{ }^{-}>\mathrm{PO}_{4}{ }^{2-}\right)$. Alkaline earths $\left(\mathrm{Ca}^{2+}\right.$ and $\left.\mathrm{Mg}^{2+}\right)$ exceed the alkalis $\left(\mathrm{Na}^{+}\right.$and $\left.\mathrm{K}^{+}\right)$and weak acids $\left(\mathrm{HCO}_{3}{ }^{-}\right.$and $\left.\mathrm{CO}_{3}{ }^{2-}\right)$ exceed strong acids $\left(\mathrm{Cl}^{-}\right.$ and $\mathrm{SO}_{4}{ }^{2-}$ ).

3. The $\mathrm{NO}_{3}{ }^{-}$values vary from 0.10 to $129 \mathrm{ppm}$ in postmonsoon (2014) and 0.07 to $135.30 \mathrm{ppm}$ in pre-monsoon 2015. The result shows $33 \%$ and $15 \%$ of the samples in POM and PRM, respectively, are above permissible limit of WHO. The fluoride values vary from
0.25 to $3.35 \mathrm{ppm}$ in POM and 0.43 to 4.25 PRM. The result shows $42 \%$ and $40 \%$ samples in POM and PRM, respectively, are above permissible limit of WHO. The high nitrate concentration is mainly due to agriculture activity, whereas rock-water interaction is major source of fluoride.

4. Majority of the samples fall in the field of mixed $\mathrm{Ca}+\mathrm{Mg}-\mathrm{HCO}_{3}, \mathrm{Ca}-\mathrm{HCO}_{3}$ and $\mathrm{Ca}+\mathrm{Na}-\mathrm{HCO} 3$ water types represent host rock contribution and anthropogenic inputs. The Gibbs's diagram revealed that the chemical weathering of rock-forming minerals is influencing the groundwater quality.

5. The results reveal that groundwater samples are under high risk and very high-risk categories, respectively, which are not suitable for drinking purposes in the study region. The $58.85 \%$ and $44.23 \%$ of samples have the HQ value for fluoride and nitrate than the tolerable limit, signifying that fluoride contributes more to the noncarcinogenic risk than nitrate for adults and children. The PRM season shows $38.46 \%$ and $55.77 \%$ fluoride hazard quotients for adults and children. While nitrate is having low hazard quotients of $21.15 \%$ and $26.92 \%$ for adult and children, respectively.

6. The total hazard index for pre-monsoon in adult's ranges from 0.43 to 4.14 , and for children 0.46 to 5.60 , for postmonsoon it varies from 0.17 to 4.94 and 0.18 to 6.03 , respectively.

7. Based on the total health risk assessment, $65.4 \%, 71.2 \%$, and $71.2 \%, 82.7 \%$ of the samples have high non-carcinogenic risk, due to exceeding the THI value 1 accepted by USEPA for Adult, and children, respectively, in postmonsoon and pre-season. It shows that children are having higher risk than adults for both seasons in study area. Hence, pollutant's filters and rainwater recharging structure are recommended as actions to lessen the health hazards. 
Table 3 Average daily dose (ADD) hazard quotient (HQ) and total hazard index (THI) for adults and children in the study area for pre-monsoon season

\begin{tabular}{|c|c|c|c|c|c|c|c|c|c|c|}
\hline \multirow[b]{2}{*}{ Sample no } & \multicolumn{5}{|l|}{ Adult } & \multicolumn{5}{|l|}{ Children } \\
\hline & ADD Fluoride & ADD Nitrate & HQ Fluoride & HQ Nitrate & THI & ADD Fluoride & ADD Nitrate & HQ Fluoride & HQ Nitrate & THI \\
\hline DW1 & 0.035 & 0.20 & 0.58 & 0.12 & 0.70 & 0.05 & 0.27 & 0.78 & 0.17 & 0.95 \\
\hline DW2 & 0.101 & 3.56 & 1.68 & 2.22 & 3.90 & 0.14 & 4.81 & 2.27 & 3.00 & 5.28 \\
\hline BW3 & 0.032 & 4.05 & 0.53 & 2.53 & 3.06 & 0.04 & 5.47 & 0.72 & 3.42 & 4.14 \\
\hline BW4 & 0.053 & 5.20 & 0.89 & 3.25 & 4.14 & 0.07 & 7.04 & 1.20 & 4.40 & 5.60 \\
\hline BW6 & 0.027 & 1.65 & 0.44 & 1.03 & 1.48 & 0.04 & 2.23 & 0.60 & 1.39 & 2.00 \\
\hline BW7 & 0.093 & 1.23 & 1.54 & 0.77 & 2.31 & 0.13 & 1.67 & 2.08 & 1.04 & 3.13 \\
\hline DW8 & 0.086 & 0.65 & 1.44 & 0.40 & 1.84 & 0.12 & 0.88 & 1.94 & 0.55 & 2.49 \\
\hline BW9 & 0.078 & 0.06 & 1.31 & 0.04 & 1.35 & 0.11 & 0.09 & 1.76 & 0.05 & 1.82 \\
\hline BW10 & 0.023 & 0.25 & 0.39 & 0.15 & 0.55 & 0.03 & 0.33 & 0.53 & 0.21 & 0.74 \\
\hline BW11 & 0.019 & 0.46 & 0.31 & 0.29 & 0.60 & 0.03 & 0.62 & 0.42 & 0.39 & 0.81 \\
\hline DW12 & 0.027 & 0.11 & 0.45 & 0.07 & 0.52 & 0.04 & 0.15 & 0.61 & 0.10 & 0.70 \\
\hline BW13 & 0.067 & 0.01 & 1.12 & 0.00 & 1.13 & 0.09 & 0.01 & 1.52 & 0.00 & 1.52 \\
\hline BW14 & 0.028 & 1.61 & 0.47 & 1.01 & 1.48 & 0.04 & 2.18 & 0.63 & 1.36 & 2.00 \\
\hline BW15 & 0.102 & 0.00 & 1.70 & 0.00 & 1.70 & 0.14 & 0.00 & 2.30 & 0.00 & 2.30 \\
\hline BW16 & 0.063 & 0.00 & 1.06 & 0.00 & 1.06 & 0.09 & 0.01 & 1.43 & 0.00 & 1.43 \\
\hline DW19 & 0.071 & 1.15 & 1.19 & 0.72 & 1.90 & 0.10 & 1.56 & 1.60 & 0.97 & 2.58 \\
\hline DW20 & 0.081 & 0.91 & 1.35 & 0.57 & 1.92 & 0.11 & 1.23 & 1.83 & 0.77 & 2.60 \\
\hline BW21 & 0.163 & 0.74 & 2.72 & 0.46 & 3.18 & 0.22 & 1.00 & 3.68 & 0.62 & 4.31 \\
\hline BW22 & 0.020 & 1.10 & 0.34 & 0.69 & 1.03 & 0.03 & 1.49 & 0.46 & 0.93 & 1.39 \\
\hline SW23 & 0.048 & 0.00 & 0.81 & 0.00 & 0.81 & 0.07 & 0.01 & 1.09 & 0.00 & 1.10 \\
\hline DW24 & 0.051 & 0.16 & 0.85 & 0.10 & 0.95 & 0.07 & 0.22 & 1.14 & 0.14 & 1.28 \\
\hline DW25 & 0.028 & 1.62 & 0.46 & 1.01 & 1.47 & 0.04 & 2.18 & 0.62 & 1.37 & 1.99 \\
\hline DW26 & 0.057 & 0.61 & 0.96 & 0.38 & 1.34 & 0.08 & 0.83 & 1.29 & 0.52 & 1.81 \\
\hline BW28 & 0.024 & 0.86 & 0.40 & 0.54 & 0.93 & 0.03 & 1.16 & 0.54 & 0.72 & 1.26 \\
\hline DW29 & 0.031 & 0.84 & 0.52 & 0.53 & 1.05 & 0.04 & 1.14 & 0.71 & 0.71 & 1.42 \\
\hline DW30 & 0.020 & 1.10 & 0.34 & 0.69 & 1.03 & 0.03 & 1.49 & 0.46 & 0.93 & 1.39 \\
\hline BW31 & 0.019 & 1.00 & 0.32 & 0.63 & 0.94 & 0.03 & 1.35 & 0.43 & 0.85 & 1.27 \\
\hline BW32 & 0.046 & 0.19 & 0.76 & 0.12 & 0.88 & 0.06 & 0.26 & 1.03 & 0.16 & 1.20 \\
\hline DW33 & 0.040 & 2.06 & 0.67 & 1.28 & 1.96 & 0.05 & 2.78 & 0.91 & 1.74 & 2.65 \\
\hline BW34 & 0.072 & 1.01 & 1.20 & 0.63 & 1.84 & 0.10 & 1.37 & 1.63 & 0.86 & 2.48 \\
\hline BW35 & 0.028 & 0.03 & 0.47 & 0.02 & 0.49 & 0.04 & 0.04 & 0.63 & 0.03 & 0.66 \\
\hline BW37 & 0.085 & 1.91 & 1.42 & 1.19 & 2.61 & 0.12 & 2.58 & 1.92 & 1.61 & 3.53 \\
\hline BW38 & 0.074 & 1.99 & 1.23 & 1.25 & 2.48 & 0.10 & 2.70 & 1.66 & 1.68 & 3.35 \\
\hline BW39 & 0.058 & 2.32 & 0.97 & 1.45 & 2.42 & 0.08 & 3.14 & 1.31 & 1.96 & 3.27 \\
\hline DW40 & 0.072 & 0.91 & 1.20 & 0.57 & 1.77 & 0.10 & 1.23 & 1.62 & 0.77 & 2.39 \\
\hline BW41 & 0.039 & 1.75 & 0.65 & 1.09 & 1.74 & 0.05 & 2.37 & 0.88 & 1.48 & 2.36 \\
\hline DW42 & 0.056 & 1.14 & 0.94 & 0.71 & 1.65 & 0.08 & 1.55 & 1.27 & 0.97 & 2.23 \\
\hline BW43 & 0.052 & 0.07 & 0.86 & 0.04 & 0.90 & 0.07 & 0.09 & 1.16 & 0.06 & 1.22 \\
\hline DW44 & 0.029 & 0.36 & 0.49 & 0.22 & 0.71 & 0.04 & 0.48 & 0.66 & 0.30 & 0.96 \\
\hline DW45 & 0.017 & 0.28 & 0.28 & 0.18 & 0.45 & 0.02 & 0.38 & 0.37 & 0.24 & 0.61 \\
\hline BW46 & 0.020 & 0.00 & 0.34 & 0.00 & 0.34 & 0.03 & 0.01 & 0.46 & 0.00 & 0.46 \\
\hline BW47 & 0.065 & 1.21 & 1.08 & 0.75 & 1.84 & 0.09 & 1.63 & 1.46 & 1.02 & 2.48 \\
\hline BW48 & 0.096 & 0.56 & 1.60 & 0.35 & 1.95 & 0.13 & 0.76 & 2.16 & 0.48 & 2.63 \\
\hline BW49 & 0.129 & 0.00 & 2.15 & 0.00 & 2.16 & 0.17 & 0.01 & 2.91 & 0.00 & 2.92 \\
\hline BW50 & 0.034 & 1.05 & 0.57 & 0.66 & 1.23 & 0.05 & 1.42 & 0.77 & 0.89 & 1.66 \\
\hline BW51 & 0.048 & 0.94 & 0.81 & 0.59 & 1.40 & 0.07 & 1.27 & 1.09 & 0.80 & 1.89 \\
\hline BW53 & 0.043 & 0.00 & 0.71 & 0.00 & 0.71 & 0.06 & 0.01 & 0.96 & 0.00 & 0.97 \\
\hline
\end{tabular}


Table 3 (continued)

\begin{tabular}{|c|c|c|c|c|c|c|c|c|c|c|}
\hline \multirow[b]{2}{*}{ Sample no } & \multicolumn{5}{|l|}{ Adult } & \multicolumn{5}{|l|}{ Children } \\
\hline & ADD Fluoride & ADD Nitrate & HQ Fluoride & HQ Nitrate & THI & ADD Fluoride & ADD Nitrate & HQ Fluoride & HQ Nitrate & THI \\
\hline DW54 & 0.075 & 0.32 & 1.24 & 0.20 & 1.44 & 0.10 & 0.43 & 1.68 & 0.27 & 1.95 \\
\hline DW55 & 0.025 & 1.22 & 0.42 & 0.76 & 1.18 & 0.03 & 1.65 & 0.57 & 1.03 & 1.60 \\
\hline BW56 & 0.083 & 1.04 & 1.38 & 0.65 & 2.03 & 0.11 & 1.41 & 1.86 & 0.88 & 2.74 \\
\hline BW57 & 0.042 & 0.82 & 0.69 & 0.51 & 1.20 & 0.06 & 1.11 & 0.94 & 0.69 & 1.63 \\
\hline BW59 & 0.070 & 1.11 & 1.17 & 0.69 & 1.86 & 0.09 & 1.50 & 1.58 & 0.94 & 2.51 \\
\hline Min & 0.017 & 0.003 & 0.276 & 0.002 & 0.342 & 0.022 & 0.004 & 0.373 & 0.002 & 0.463 \\
\hline Max & 0.163 & 5.204 & 2.724 & 3.252 & 4.142 & 0.221 & 7.036 & 3.683 & 4.397 & 5.600 \\
\hline Average & 0.056 & 1.049 & 0.934 & 0.656 & 1.557 & 0.076 & 1.418 & 1.263 & 0.886 & 2.105 \\
\hline
\end{tabular}

Fig. 8 a The comparison between total hazard index with Adult and children in the study region for post-monsoon season. b The comparison between total hazard index with Adult and children in the study region for pre-monsoon season

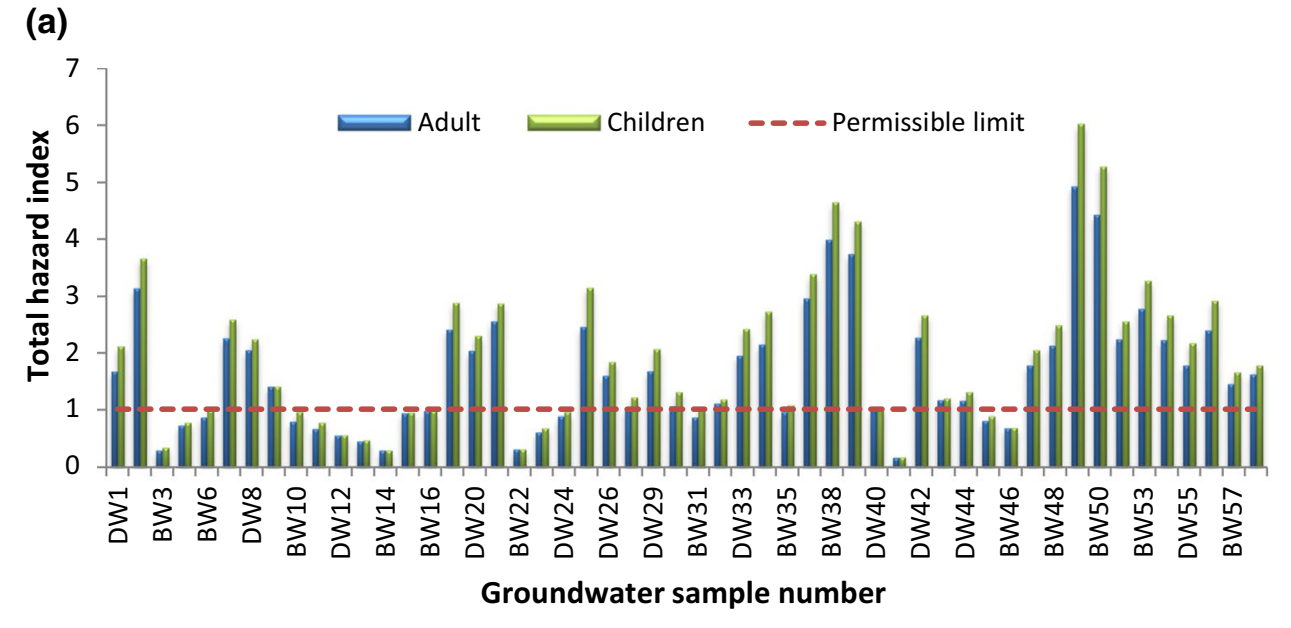

(b)

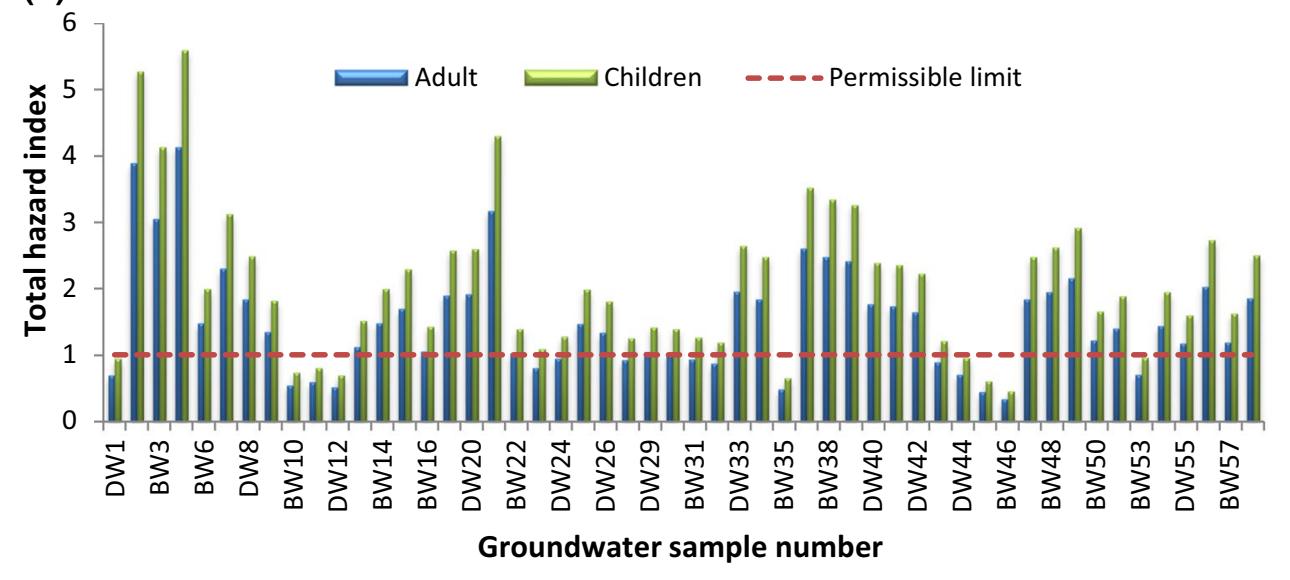




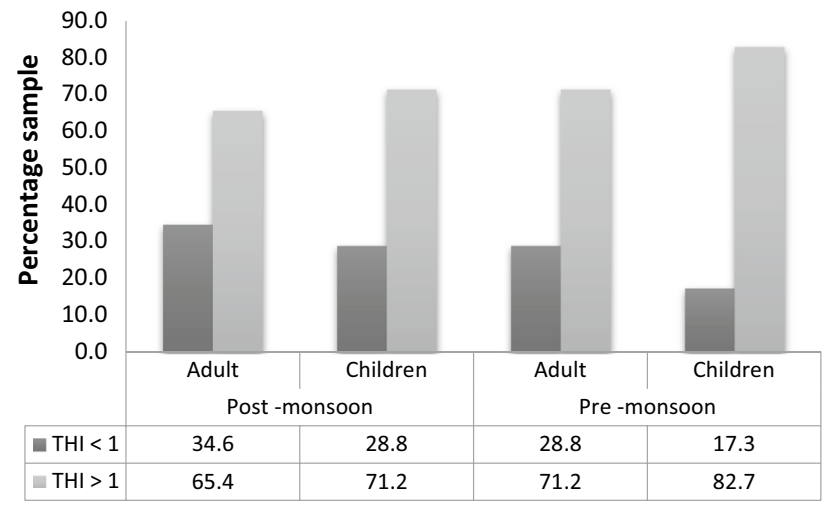

Fig. 9 Total hazard index value in percentage with Adult and children for both seasons

Acknowledgements Authors of the manuscript are thankful to Department of Science and Technology, for providing funding to the research article.

Funding First Author is thankful to Department of Science and Technology ((SR/FTP/ES-45/2013)) for providing funding to the research study.

\section{Compliance with ethical standards}

Conflict of interest The authors declare that they have no conflict of interest.

Open Access This article is licensed under a Creative Commons Attribution 4.0 International License, which permits use, sharing, adaptation, distribution and reproduction in any medium or format, as long as you give appropriate credit to the original author(s) and the source, provide a link to the Creative Commons licence, and indicate if changes were made. The images or other third party material in this article are included in the article's Creative Commons licence, unless indicated otherwise in a credit line to the material. If material is not included in the article's Creative Commons licence and your intended use is not permitted by statutory regulation or exceeds the permitted use, you will need to obtain permission directly from the copyright holder. To view a copy of this licence, visit http://creativecommons.org/licenses/by/4.0/.

\section{References}

Adimalla N, Li P (2019) Occurrence, health risks, and geochemical mechanisms of fluoride and nitrate in groundwater of the rockdominant semi-arid region, Telangana State, India. Hum Ecol Risk Assess Int J 25(1-2):81-103

Adimalla N, Li P, Qian H (2019) Evaluation of groundwater contamination for fluoride and nitrate in semi-arid region of Nirmal Province, South India: a special emphasis on human health risk assessment (HHRA). Hum Ecol Risk Assess Int J 25(5):1107-1124

Ahada CPS, Suthar S (2018) Groundwater nitrate contamination and associated human health risk assessment in southern districts of Punjab. Environ Sci Pollut Res, India, p 12
APHA (1995) Standard methods for the examinations of water and waste water, 19th edn. American Public Health Association, Washington

Ayoob S, Gupta AK (2006) Fluoride in drinking water: a review on the status and stress effects. Crit Rev Environ Sci Technol 36(6):433-487

Bahrami M, Zarei AR, Rostami F (2020) Temporal and spatial assessment of groundwater contamination with nitrate by nitrate pollution index (NPI) and GIS (case study: Fasarud Plain, southern Iran). Environ Geochem Health. https://doi.org/10.1007/s1065 3-020-00546-X

Bose PN (1984) Geology of the lower Narmada valley between Nirmawar and Kawant. Geol Surv India 21(1):1-72

Brindha K, Elango L (2014) Geochemische Modellierung von Einflüssen Einer Geplanten Absetzanlage für Urantailings auf die Grundwasserbeschaffenheit. Mine Water Environ 33:110-120. https://doi.org/10.1007/s10230-014-0279-3

Brindha K, Pavelic P, Sotoukee T et al (2017a) Geochemical characteristics and groundwater quality in the Vientiane plain, Laos. Expos Heal 9:89-104. https://doi.org/10.1007/s12403-016-0224-8

Brindha K, Renganayaki SP, Elango L (2017b) Sources, toxicological effects and removal techniques of nitrates in groundwater: an overview. Indian J Environ Prot 37:667-700

Chen J, Wu H, Qian H, Gao Y (2017) Assessing nitrate and fluoride contaminants in drinking water and their health risk of rural residents living in a semiarid region of northwest China. Expos Health 9:183-195. https://doi.org/10.1007/s12403-016-0231-9

Daniel J, Karuppasamy S (2012) Evaluation of fluoride contamination in groundwater using remote sensing and GIS techniques in Virudhunagar District. Int J Adv Remote Sens GIS 1:12-19

Datta PS, Tyagi SK (1996) Major ion chemistry of groundwater Delhi area: chemical weathering processes and groundwater flow regime. Geol Soc India 47(2):179-188. https://doi.org/10.12691 ljgg-2-5A-4

Domenico PA, Schwartz FW (1990) Physical and chemical hydrogeology. Wiley, New York

Egbi CD, Anornu GK, Ganyaglo SY, Appiah-Adjei EK, Li SL, Dampare SB (2020) Nitrate contamination of groundwater in the Lower Volta River Basin of Ghana: sources and related human health risks. Ecotoxicol Environ Saf 191:110227

Fabro AYR, Ávilaa JGP, Alberichb MVE, Sansoresa SAC, CamargoValero MA (2015) Spatial distribution of nitrate health risk associated with groundwater use as drinking water in Merida, Mexico. Appl Geogr 65:49-57

Gibbs RJ (1970) Mechanisms controlling world water chemistry. Sci J 170:795-840. https://doi.org/10.1126/science.170.3962.1088

Hamdi M, Zagrarni MF, Jerbi H, Tarhouni J (2018) Hydrogeochemical and isotopic investigation and water quality assessment of groundwater in the Sisseb El Alem Nadhour Saouaf aquifer (SANS), northeastern Tunisia. J Afr Earth Sc 141:148-163

Höckenreiner M, Neugebauer H, Elango L (2015) Ex situ bioremediation method for the treatment of groundwater contaminated with PAHs. Int J Environ Sci Technol 12:285-296. https://doi. org/10.1007/s13762-013-0427-5

Huang G, Sun J, Zhang Y et al (2013) Impact of anthropogenic and natural processes on the evolution of groundwater chemistry in a rapidly urbanized coastal area, South China. Sci Total Environ. https://doi.org/10.1016/j.scitotenv.2013.05.078

Huber García V, Meyer S, Kok K et al (2018) Deriving spatially explicit water uses from land use change modelling results in four river basins across Europe. Sci Total Environ 628-629:1079-1097. https://doi.org/10.1016/j.scitotenv.2018.02.051

Jiang Y, Wu Y, Groves C et al (2009) Natural and anthropogenic factors affecting the groundwater quality in the Nandong karst 
underground river system in Yunan, China. J Contam Hydrol 109:49-61. https://doi.org/10.1016/j.jconhyd.2009.08.001

Kadam A, Wagh V, Umrikar B et al (2019) An implication of boron and fluoride contamination and its exposure risk in groundwater resources in semi-arid region. Environ Dev Sustain, Western India. https://doi.org/10.1007/s10668-019-00527-w

Kale S, Pawar NJ (2017) Fluoride accumulation in groundwater from semi-arid part of Deccan Volcanic Province, India: a cause of urolithiasis outbreak. Hydrospatial Anal 1:9-17. https://doi. org/10.21523/gcj3.17010102

Kammoun S, Trabelsi R, Re V et al (2018) Groundwater quality assessment in semi-arid regions using integrated approaches: the case of Grombalia aquifer (NE Tunisia). Environ Monit Assess. https ://doi.org/10.1007/s10661-018-6469-x

Karande UB, Kadam A, Umrikar BN et al (2020) Environmental modelling of soil quality, heavy-metal enrichment and human health risk in sub-urbanized semiarid watershed of western India. Model Earth Syst Environ 6:545-556. https://doi.org/10.1007/s4080 8-019-00701-z

Karyab H, Hajimirmohammad-Ali R, Bahojb A (2019) A lumpedparameter model for investigation of nitrate concentration in drinking water in arid and semi-arid climates and health risk assessment. J Environ Health Sci Eng 17(1):457-465

Kumar P, Thakur PK, Bansod BKS, Debnath SK (2017) Groundwater: a regional resource and a regional governance. Environ Dev Sustain. https://doi.org/10.1007/s10668-017-9931-y

Kumar P, Masago Y, Kumar B, Fukushi K (2018) Groundwater for sustainable development evaluating future stress due to combined effect of climate change and rapid urbanization for Pasig-Marikina River, Manila. Groundw Sustain Dev 6:227-234. https://doi. org/10.1016/j.gsd.2018.01.004

Lawniczak AE, Zbierska J, Nowak B, Achtenberg K, Grześkowiak A, Kanas K (2016) Impact of agriculture and land use on nitrate contamination in groundwater and running waters in central-west Poland. Environ Monit Assess 188(3):172

Li P, Wu J, Qian H et al (2014) Origin and assessment of groundwater pollution and associated health risk: a case study in an industrial park, northwest China. Environ Geochem Health 36:693-712. https://doi.org/10.1007/s10653-013-9590-3

Li P, Li X, Meng X, Li M, Zhang Y (2016a) Appraising groundwater quality and health risks from contamination in a semiarid region of northwest China. Expos Health 8(3):361-379. https://doi. org/10.1007/s12403-016-0205-y

Li F, Zhang J, Huang J, Huang D, Yang J, Song Y, Zeng G (2016b) Heavy metals in road dust from Xiandao District, Changsha City, China: characteristics, health risk assessment, and integrated source identification. Environ Sci Pollut Res 23(13):13100-13113

Lu Y, Sun ZR, Wu LN, Wang X, Lu W, Liu SS (2000) Effect of highfluoride water on intelligence in children. Fluoride 33(2):75-78

Magesh NS, Chandrasekar N, Elango L (2017) Trace element concentrations in the groundwater of the Tamiraparani river basin, South India: insights from human health risk and multivariate statistical techniques. Chemosphere 185:468-479. https://doi.org/10.1016/j. chemosphere.2017.07.044

Mrazovaca S, Miloradov MV, Matic I, Maric N (2013) Multivariate statistical analysis of chemical parameters of groundwater in Vojvodina. Chem Erde 73:217-225. https://doi.org/10.1016/j. chemer.2012.11.002

Mukherjee I, Singh UK (2018) Groundwater fluoride contamination, probable release, and containment mechanisms: a review on Indian context. Environ Geochem Health 40(6):2259-2301

Mundalik V, Fernandes C, Kadam AK, Umrikar BN (2018) Integrated geomorphological, geospatial and AHP technique for groundwater prospects mapping in Basaltic Terrain article history. Hydrospatial Anal 2:16. https://doi.org/10.21523/gcj3.18020102
Narsimha A, Rajitha S (2018) Spatial distribution and seasonal variation in fluoride enrichment in groundwater and its associated human health risk assessment in Telangana State, South India. Hum Ecol Risk Assess Int J 24(8):2119-2132

Ostad-Ali-Askari K, Shayannejad M, Ghorbanizadeh-Kharazi H (2017) Artificial neural network for modeling nitrate pollution of groundwater in marginal area of Zayandeh-rood River, Isfahan, Iran. KSCE J Civ Eng 21:134-140. https://doi.org/10.1007/s1220 5-016-0572-8

Pastén-Zapata E, Ledesma-Ruiz R, Harter T et al (2014) Assessment of sources and fate of nitrate in shallow groundwater of an agricultural area by using a multi-tracer approach. Sci Total Environ. https://doi.org/10.1016/j.scitotenv.2013.10.043

Pawar NJ (1993) Geochemistry of carbonate precipitation from groundwaters in basaltic aquifers: an equilibrium thermodynamic approach. J Geol Soc India 41:119-131

Pawar NJ, Shaikh IJ (1995) Nitrate pollution of groundwaters from shallow basaltic aquifers, Deccan Trap Hydrogeologic Province, India. Environ Geol 25:197-204

Pawar NJ, Pawar JB, Kumar S, Supekar A (2008) Geochemical eccentricity of ground water allied to weathering of basalts from the Deccan Volcanic Province, India: insinuation on $\mathrm{CO}_{2}$ consumption. Aquat Geochem 14(1):41-71

Piper AM (1953) A graphic procedure in the geochemical interpretation of water analyses. U.S. Geol. Survey, Groundwater, p 12

Quijano L, Yusà V, Font G, McAllister C, Torres C, Pardo O (2017) Risk assessment and monitoring programme of nitrates through vegetables in the Region of Valencia (Spain). Food Chem Toxicol 100:42-49

Ramesh K, Elango L (2012) Groundwater quality and its suitability for domestic and agricultural use in Tondiar river basin, Tamil Nadu, India. Environ Monit Assess 184:3887-3899. https://doi. org/10.1007/s10661-011-2231-3

Rezaei H, Jafari A, Kamarehie B, Fakhri Y, Ghaderpoury A, Karami MA, Salimi M (2019) Health-risk assessment related to the fluoride, nitrate, and nitrite in the drinking water in the Sanandaj, Kurdistan County, Iran. Hum Ecol Risk Assess Int J 25(5):1242-1250

Saidi S, Bouri S, Dhia HB, Anselme B (2009) A GIS-based susceptibility indexing method for irrigation and drinking water management planning: application to Chebba-Mellouleche Aquifer, Tunisia. Agric Water Manag 96(12):1683-1690

Singh A (2014) Agricultural water management simulation-optimization modeling for conjunctive water use management. Agric Water Manag 141:23-29. https://doi.org/10.1016/j.agwat .2014 .04 .003

Singh A, Panda SN, Kumar KS, Sharma CS (2013) Artificial groundwater recharge zones mapping using remote sensing and gis: a case study in Indian Punjab. Environ Manag 52:61-71. https:// doi.org/10.1007/s00267-013-0101-1

Singh S, Raju NJ, Ramakrishna C (2015) Evaluation of groundwater quality and its suitability for domestic and irrigation use in parts of the Chandauli-Varanasi. J Water Resour Prot 7:572-587

Singh G, Kumari B, Sinam G, Kumar N, Mallick S (2018) Fluoride distribution and contamination in the water, soil and plants continuum and its remedial technologies, an Indian perspective-a review. Environ pollut 239:95-108

Su C, Wang Y, Xie X, Li J (2013) Aqueous geochemistry of high-fluoride groundwater in Datong Basin, Northern China. J Geochem Explor 135:79-92

Surendran U, Sushanth CM, Mammen G, Joseph EJ (2017) FAOCROPWAT model-based estimation of crop water need and appraisal of water resources for sustainable water resource management: pilot study for Kollam District-Humid Tropical Region of Kerala, India. Curr Sci 112:76. https://doi.org/10.18520/cs/ v112/i01/76-86

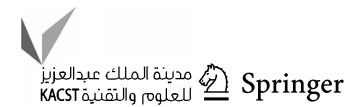


Suthar S, Bishnoi P, Singh S, Mutiyar PK, Nema AK, Patil NS (2009) Nitrate contamination in groundwater of some rural areas of Rajasthan, India. J Hazard Mater 171:189-199

Taiwo AM (2012) Source identification and apportionment of pollution sources to groundwater quality in major cities in Southwest, Nigeria. Geofizika 29(2):157-174

USEPA (1991) Risk assessment guidance for superfund, vol 1: human health evaluation manual (Part B, Development of risk-based preliminary remediation goals). EPA-9585.7-01B. Office of Emergency and Remedial Response, Washington, DC

USEPA (2006) USEPA Region III risk-based concentration table: Technical background information. United States Environmental Protection Agency, Washington, DC

USEPA (2014) Human health evaluation manual, supplemental guidance: update of standard default exposure factors-OSWER Directive 9200.1-120. PP.6

Vetrimurugan E, Elango L (2015a) Groundwater chemistry and quality in an intensively cultivated river delta. Water Qual Expo Heal 7:125-141. https://doi.org/10.1007/s12403-014-0133-7

Vetrimurugan E, Elango L (2015b) Groundwater chemistry and quality in an intensively cultivated river delta. Water Qual Expos Health 7(2):125-141

Vetrimurugan E, Elango L, Rajmohan N (2013) Sources of contaminants and groundwater quality in the coastal part of a river delta. Int J Environ Sci Technol 10:473-486. https://doi.org/10.1007/ s13762-012-0138-3

Wagh VM, Panaskar DB, Muley AA (2017) Estimation of nitrate concentration in groundwater of Kadava river basin-Nashik district,
Maharashtra, India by using artificial neural network model. Model Earth Syst Environ 3:36. https://doi.org/10.1007/s4080 8-017-0290-3

Wagh V, Panaskar D, Muley A et al (2018) Neural network modelling for nitrate concentration in groundwater of Kadava River basin, Nashik, Maharashtra, India. Groundw Sustain Dev. https://doi. org/10.1016/j.gsd.2017.12.012

Wagh VM, Panaskar DB, Mukate SV, Aamalawar ML, Laxman Sahu U (2020) Nitrate associated health risks from groundwater of Kadava river basin Nashik, Maharashtra, India. Hum Ecol Risk Assess Int J 26(3):654-672

Wang S, Tang C, Song X et al (2016) Factors contributing to nitrate contamination in a groundwater recharge area of the North China Plain. Hydrospatial Anal 2285:2271-2285. https://doi. org/10.1002/hyp.10778

West WD (1962) The line of Narmada-Valley. Curr Sci 31:143-144

Wu J, Sun Z (2016) Evaluation of shallow groundwater contamination and associated human health risk in an alluvial plain impacted by agricultural and industrial activities, mid-west China. Expos Health 8:311-329. https://doi.org/10.1007/s12403-015-0170-x

Yousefi M, Ghoochani M, Hossein Mahvi A (2018) Health risk assessment to fluoride in drinking water of rural residents living in the Poldasht city, Northwest of Iran. Ecotoxicol Environ Saf 148:426430. https://doi.org/10.1016/j.ecoenv.2017.10.057

Publisher's Note Springer Nature remains neutral with regard to jurisdictional claims in published maps and institutional affiliations. 